\title{
Cellular effects of paclitaxel-loaded iron oxide nanoparticles on breast cancer using different 2D and 3D cell culture models
}

This article was published in the following Dove Medical Press journal: International Journal of Nanomedicine

\author{
Stephan Lugert ${ }^{1,2}$ \\ Harald Unterweger ${ }^{\prime}$ \\ Marina Mühlberger' \\ Christina Janko' \\ Sebastian Draack ${ }^{3}$ \\ Frank Ludwig ${ }^{3}$ \\ Dietmar Eberbeck ${ }^{4}$ \\ Christoph Alexiou' \\ Ralf P Friedrich' \\ 'Department of Otorhinolaryngology, \\ Head and Neck Surgery, Section \\ of Experimental Oncology and \\ Nanomedicine (SEON), Else Kröner- \\ Fresenius-Stiftung-Professorship, \\ Universitätsklinikum Erlangen, \\ Erlangen, Germany; ${ }^{2}$ Friedrich- \\ Alexander-Universität Erlangen- \\ Nürnberg (FAU), Erlangen, Germany; \\ ${ }^{3}$ Institut für Elektrische Messtechnik \\ und Grundlagen der Elektrotechnik, \\ TU Braunschweig, Braunschweig, \\ Germany; ${ }^{4}$ Physikalisch-Technische \\ Bundesanstalt Braunschweig und \\ Berlin, Berlin, Germany
}

Correspondence: Ralf P Friedrich Department of Otorhinolaryngology, Head and Neck Surgery, Section of Experimental Oncology and Nanomedicine, Universitätsklinikum Erlangen, Glückstrasse I0a, 91054 Erlangen, Germany Tel +49 9|3| 8533 |42 Fax +49 9|3। 8534828

Email ralf.friedrich@uk-erlangen.de
Background: Magnetic drug targeting (MDT) is an effective alternative for common drug applications, which reduces the systemic drug load and maximizes the effect of, eg, chemotherapeutics at the site of interest. After the conjugation of a magnetic carrier to a chemotherapeutic agent, the intra-arterial injection into a tumor-afferent artery in the presence of an external magnetic field ensures the accumulation of the drug within the tumor tissue.

Materials and methods: In this study, we used superparamagnetic iron oxide nanoparticles (SPIONs) coated with lauric acid and human serum albumin as carriers for paclitaxel (SPION $\left.{ }^{\text {LA-HSA-Ptx }}\right)$. To investigate whether this particle system is suitable for a potential treatment of cancer, we investigated its physicochemical properties by dynamic light scattering, $\zeta$ potential measurements, isoelectric point titration, infrared spectroscopy, drug release quantification, and magnetic susceptibility measurements. The cytotoxic effects were evaluated using extensive toxicological methods using flow cytometry, IncuCyte ${ }^{\circledR}$ live-cell imaging, and growth experiments on different human breast cancer cell lines in two- and three-dimensional cell cultures. Conclusion: The data showed that next to their high magnetization capability, SPION ${ }^{\text {LA-HSA-Ptx }}$ have similar cytostatic effects on human breast cancer cells as pure paclitaxel, suggesting their usage for future MDT-based cancer therapy.

Keywords: superparamagnetic iron oxide nanoparticles, SPIONs, three-dimensional cell culture, toxicity, flow cytometry, magnetic drug targeting

\section{Introduction}

Heart disease and cancer are still the first and second leading causes of death, but the risk of death from heart disease is declining faster. If the current trend persists, cancer will become the leading cause of death in the USA by $2020 .{ }^{1}$ In 2012 , there were 1.67 million cases of newly diagnosed breast cancer worldwide; thus, breast cancer is the second most common cancer only exceeded by lung cancer with 1.82 million newly diagnosed cases. ${ }^{2}$ Considering only women, it is even the most common type, and the incidents are believed to rise even further due to the increase of several risk factors such as overweight, sedentary lifestyle, and hormonal exposition increase. ${ }^{3}$ Despite these high numbers, the mortality has significantly decreased over the last few decades, but there were still 522,000 deaths in 2012. ${ }^{2}$ An early detection of cancer is provided by screening programs and has led to increased survival rates by early intervention.

The options for treatment are surgery, immune therapy, radiation, and/or chemotherapy, which can be adjuvantly or neoadjuvantly used., ${ }^{45}$ One frequently used chemotherapeutic antitumor agent, especially effective against ovarian and breast cancer, is paclitaxel (Ptx), a taxane, which stabilizes microtubules and, as a consequence, 
inhibits mitosis. ${ }^{6}$ Like all chemotherapeutics, Ptx is commonly administered systemically where only a small part of the drug is delivered to the tumor, while the majority reaches and affects other areas of the body, triggering severe side effects, such as bone marrow suppression and neurotoxicity. ${ }^{7}$ Occasionally, these side effects are too severe, forcing the termination of the treatment even in patients who have no alternative left. Thus, it is crucial to find a strategy to accumulate the drug at the tumor site and simultaneously decrease the concentration in the rest of the body. This targeted drug delivery can be achieved by magnetic drug targeting (MDT), where drug-loaded magnetic particles are injected into the vascular system upstream from the malignant tissue and captured at the tumor site using an applied magnetic field. ${ }^{8-10}$ This method dramatically increases the amount of chemotherapeutics within the tumor, enabling strong antitumor effects with a reduced dosage and minimalized side effects. ${ }^{11-14}$

In this study, we manufactured Ptx-functionalized superparamagnetic iron oxide nanoparticles (SPIONs) coated with lauric acid (LA) and human serum albumin (HSA; SPION $\left.^{\text {LA-HSA-Ptx }}\right)$ in order to evaluate the efficiency and reasonableness for future preclinical applications in breast cancer animal models. After a detailed physicochemical nanoparticle characterization, the effects on the viability and proliferation of four different breast cancer cell lines were investigated in two-dimensional (2D) and three-dimensional (3D) cell cultures. To address the heterogeneity of breast cancer cells, we investigated the effects on T-47D, BT-474, MCF-7, and MDA-MB-231 cells, belonging to different subtypes, as defined by receptor expression and proliferation rates. ${ }^{15,16}$ The efficiency of SPION ${ }^{\text {LA-HSA-Ptx }}$ was analyzed in comparison with Ptx alone and Ptx-free SPIONs (SPION ${ }^{\text {LA-HSA }}$ ).

\section{Materials and methods Materials}

Iron(II) chloride tetrahydrate $\left(\mathrm{FeCl}_{2} \cdot 4 \mathrm{H}_{2} \mathrm{O}\right)$, hydroxylammonium chloride, and Eppendorf ultrafiltration tubes with a molecular weight cutoff (MWCO) of $3 \mathrm{kDa}$ were obtained from Merck (Darmstadt, Germany). Iron reference standards (1 g/L) were bought from Bernd Kraft GmbH (Duisburg, Germany). Recombinant HSA without octanoate stabilization $\left(\right.$ AlbIX ${ }^{\circledR}$ ) was purchased from Albumedix (Nottingham, England). Agarose, ammonia solution 25\%, ammonium chloride, formic acid, hydrochloric acid $25 \%$, dialysis tubes (Spectra/Por ${ }^{\circledR} 6$, MWCO 8 kDa), sterile Rotilabo ${ }^{\circledR}$ syringe filters with cellulose-mixed ester membranes, and iron (III) chloride hexahydrate $\left(\mathrm{FeCl}_{3} \cdot 6 \mathrm{H}_{2} \mathrm{O}\right)$ were purchased from Roth (Karlsruhe, Germany). Acetate, ammonium formate, LA, Eagle's minimum essential medium (MEM), nonessential amino acid (NEAA) solution, $\mathrm{PBS}$, propidium iodide (PI), ribonuclease $\mathrm{A}$, sodium citrate, $\mathrm{TPP}^{\circledR}$ tissue culture plates (with six, 24, and 96 wells), and Triton X-100 were purchased from Sigma-Aldrich (St Louis, MO, USA). Ringer's solution was purchased from Fresenius Kabi AG (Bad Homburg, Germany). Annexin A5 (AxV)-fluorescein isothiocyanate (FITC), Hoechst 33342 (Hoe), 1,1',3,3,3',3'hexamethylindodicarbocyanine iodide $\left(\mathrm{DiIC}_{1}(5)\right)$, L-glutamine, and Roswell Park Memorial Institute (RPMI)1640 were purchased from Thermo Fisher Scientific (Waltham, MA, USA); 15- and 50-mL centrifuge tubes were obtained from Sarstedt (Nümbrecht, Germany). Ptx was purchased from Tokyo Chemical Industry (Tokyo, Japan). Panexin and trypsin were obtained from PAN Biotech (Aidenbach, Germany). Fetal bovine serum (FBS) and Dulbecco's Modified Eagle's Medium (DMEM) were provided by Biochrom (Berlin, Germany). Human insulin was obtained from Sanofi (Paris, France). Water used in all experiments was of ultrapure quality.

\section{Synthesis of nanoparticles}

\section{Synthesis of in situ coated LA SPIONs (SPION ${ }^{L A}$ )}

The synthesis of SPION ${ }^{\mathrm{LA}}$ was performed as described by Zaloga et $\mathrm{al}^{17}$ and Bica et al. ${ }^{18}$ In short, ultrapure water was used to dissolve iron(II) and iron(III) salts. The solution was heated up to $90^{\circ} \mathrm{C}$, and while constantly stirring, an argon flow was applied and $20 \mathrm{~mL}$ of $25 \% \mathrm{NH}_{3}$ solution was added to precipitate the iron oxides. Finally, LA dissolved in acetone was added, leading to a brown colloid, which was purified by multiple dialysis.

\section{Synthesis of LA- and HSA-coated nanoparticles (SPION ${ }^{\text {LA-HSA }}$ )}

SPION ${ }^{\text {LA-HSA }}$ were synthesized according to a previously published protocol. ${ }^{17}$ A $10 \%(\mathrm{w} / \mathrm{v})$ AlbIX $^{\circledR}$ solution was filtrated through a $0.22-\mu \mathrm{m}$ sterile filter and dialyzed against ultrapure water using a dialysis bag with an MWCO of $8 \mathrm{kDa}$. Tangential ultrafiltration ( $\mathrm{MWCO}=30 \mathrm{kDa}$ ) was used to concentrate the solution followed by filtration through a $0.22-\mu \mathrm{m}$ sterile filter. Then, the albumin solution was stirred at room temperature (RT) at $200 \mathrm{rpm}$, while dropwise adding SPION $^{\mathrm{LA}}$ particles through a $0.8-\mu \mathrm{m}$ syringe filter. After 10 further minutes of constant stirring, the excess albumin was removed via tangential flow filtration. ${ }^{19}$ The particle suspensions were sterilized using a $0.22-\mu \mathrm{m}$ syringe filter and stored at the optimum storage temperature of $4^{\circ} \mathrm{C}$ until usage. ${ }^{20}$ 


\section{Synthesis of Ptx-functionalized SPION ${ }^{\text {LA-HSA }}$} (SPION LA-HSA-Ptx)

Ptx was dissolved in $5 \mathrm{mg} / \mathrm{mL}$ ethanol; $470 \mu \mathrm{L}$ SPION $^{\text {LA-HSA }}$ were mixed with $30 \mu \mathrm{L}$ Ptx solution and stirred for 2 hours to achieve SPION ${ }^{\text {LA-HSA-Ptx }}$ with $0.3 \mathrm{mg}$ Ptx $/ \mathrm{mL}$ and $4.88 \mathrm{mg}$ $\mathrm{Fe} / \mathrm{mL}$. To remove possible excess Ptx, the mixture was diluted to $15 \mathrm{~mL}$ and centrifuged at $8,000 \mathrm{~g}$. The supernatant was removed. The removal process was repeated two times. A sole Ptx solution for control experiments was made using the same concentration of Ptx and HSA. The mixture was stirred at RT for 2 hours.

\section{Characterization of nanoparticles Iron quantification}

The total iron content was determined using an Agilent 4200 microwave plasma-atomic emission spectrometer (MP-AES; Agilent Technologies, Santa Clara, CA, USA). The ferrofluids were diluted with ultrapure water. Subsequently, the diluted samples were dissolved in $65 \%$ nitric acid for 10 minutes at $95^{\circ} \mathrm{C}$. After cooling to RT, samples were further diluted with $\mathrm{H}_{2} \mathrm{O}$. The iron content was then determined with MP-AES using a commercial iron solution as the external standard. The calibration curve was prepared with iron concentrations ranging from 0.05 to $5.0 \mathrm{mg} / \mathrm{L}$.

\section{Dynamic light scattering (DLS)}

The hydrodynamic particle size and the polydispersity index (PDI) were determined in water and cell culture media using a Zetasizer Nano ZS (Malvern Panalytical, Almelo, the Netherlands). The particles were diluted to a total iron concentration of $50 \mu \mathrm{g} / \mathrm{mL}$ using ultrapure water, FBS-free RPMI-1640, and DMEM and cell culture medium supplemented with $10 \%$ FBS and measured in triplicate at $25^{\circ} \mathrm{C}$. After 7 days at $4^{\circ} \mathrm{C}$, the samples were measured again to obtain the information about the stability of the particles.

\section{Ptx release experiment}

A dialysis bag with an MWCO of $10 \mathrm{kDa}$ was filled with $2.5 \mathrm{~mL}$ RPMI cell culture medium with $10 \% \mathrm{FBS}$ and $2.5 \mathrm{~mL}$ Ptx dissolved in ethanol $(300 \mu \mathrm{g} / \mathrm{mL})$, resulting in a total Ptx concentration of $150 \mu \mathrm{g} / \mathrm{mL}$ inside the dialysis bag. This dialysis bag was placed in a sealed beaker filled with $95 \mathrm{~mL}$ RPMI with 10\% FBS and shaken in an incubator shaker at $150 \mathrm{rpm}$ and $37^{\circ} \mathrm{C}$. After determined periods, $1 \mathrm{~mL}$ of the liquid was taken out and replaced by another milliliter cell culture medium with FBS. The removed liquid was freeze-dried, and the Ptx content was determined with high-performance liquid chromatography. To determine the release of Ptx from the SPION ${ }^{\mathrm{LA}-\mathrm{HSA}-\mathrm{Ptx}}$, the same experiment was done with $2.5 \mathrm{~mL}$ of SPION ${ }^{\text {LA-HSA-Ptx }}$ containing a Ptx concentration of $300 \mu \mathrm{g} / \mathrm{mL}$.

$\zeta$ Potential and $\mathrm{pH}$ titration for the determination of the isoelectric point (IEP)

A Stabino (Particle Metrix, Meerbusch, Germany) titration device was used for the determination of the $\zeta$ potential's $\mathrm{pH}$ dependency and of the IEP. The particle concentration was set to $100 \mu \mathrm{g} \mathrm{Fe} / \mathrm{mL}$ in an aqueous dispersion, and the $\mathrm{pH}$ was adjusted with $0.02 \mathrm{M} \mathrm{HCl}$ and $0.02 \mathrm{M} \mathrm{NaOH}$, respectively. For the measurement, a $400-\mu \mathrm{m}$ piston was used with a mixing time of 10 seconds and a titration step volume of $10 \mu \mathrm{L}$.

\section{Fourier transform infrared spectroscopy} SPION $^{\text {LA-HSA }}$, SPION ${ }^{\text {LA-HSA-Ptx }}$, and free Ptx were investigated with a Bruker ALPHA Fourier transform infrared spectroscopy (FTIR) spectrometer (Bruker Corporation, Billerica, MA, USA) in an attenuated total reflection mode with an excitation wavenumber in the mid-infrared region from 400 to $4,000 \mathrm{~cm}^{-1}$ and a step size of $0.5 \mathrm{~cm}^{-1}$.

\section{Magnetic characterization}

\section{$\mathrm{M}(\mathrm{H})$ measurement}

The static response of the sample magnetization to the applied magnetic fields, ie, the $\mathrm{M}(\mathrm{H})$ curve, was measured at $295 \mathrm{~K}$ using a commercial susceptometer (MPMS XL5; Quantum Design Inc., San Diego, CA, USA). The data were corrected with respect to the magnetization of the empty sample holder as well as the dispersion medium. In order to get the specific magnetization $\mathrm{M}, \mathrm{M}$ was divided by the volume fraction of magnetite, $\phi$, which is calculated from the iron content of the sample.

\section{AC susceptometry (ACS) measurement}

ACS data were acquired at $295 \mathrm{~K}$ using home-built setups at the Technical University Braunschweig. The magnetic susceptibility of the samples was recorded as a function of the excitation frequency of the applied magnetic field. Data of a low-frequency setup (10 Hz $<f<10 \mathrm{kHz})$ and a highfrequency setup ( $200 \mathrm{~Hz}<f<1 \mathrm{MHz}$ ) were merged in one single plot. Each measurement was corrected by a blank measurement.

\section{Blood stability assay}

Blood stability of SPIONs was investigated according to a modified protocol published by Poller et $\mathrm{al}^{21} ; 200 \mu \mathrm{L}$ of freshly drawn human blood samples, stabilized with 
ethylenediaminetetraacetic acid (EDTA) or citrate, was incubated with $100 \mu \mathrm{L}$ ferrofluid ( $4.24 \mathrm{mg} \mathrm{Fe} / \mathrm{mL}$ ) for 45 minutes $(n=3)$. Then, $2 \mu \mathrm{L}$ of the respective sample was streaked on a glass slide and investigated with a Zeiss Axio Observer Z1 microscope (Zeiss, Jena, Germany). As a positive control for nonstable nanoparticles, we used SPIONs coated with LA and aminated HSA (SPION ${ }^{\mathrm{LA}-\mathrm{HSA}-\mathrm{NH} 2}$ ) produced after a modified protocol published in Mühlberger et al. ${ }^{22} \mathrm{H}_{2} \mathrm{O}$ was used as a negative control.

\section{Cell culture and sample preparation Cell culture}

Breast cancer cell lines MCF-7 (American Type Culture Collection [ATCC $]^{\circledR}$ HTB-22 ${ }^{\mathrm{TM}}$ ), T-47D (ATCC ${ }^{\circledR}$ HTB$\left.133^{\mathrm{TM}}\right), \mathrm{BT}-474$ (ATCC ${ }^{\circledR}$ HTB-20 $^{\mathrm{TM}}$ ), and MDA-MB-231 (ATCC ${ }^{\circledR}$ HTB-26 ${ }^{\mathrm{TM}}$ ) were purchased from ATCC (Manassas, VA, USA). MCF-7 cells were cultivated in DMEM (F0475) with $10 \%$ FBS and 2 mM L-glutamine; T-47D cells in RPMI1640 with $10 \%$ FBS, 0.1 units/mL human insulin, and $2 \mathrm{mM}$ L-glutamine; BT-474 cells in DMEM (F0445) with 8\% FBS, 12\% Panexin, and $2 \mathrm{mM}$ L-glutamine; and MDA-MB-231 cells in DMEM (FG0445) with 10\% FBS, 1\% MEM NEAA, and $2 \mathrm{mM}$ L-glutamine. All the cells were cultured at $37^{\circ} \mathrm{C}$ with $5 \% \mathrm{CO}_{2}$. Passaging was performed according to the manufacturer's instructions.

\section{Preparation of cell-based experiments}

Depending on the experiment, the cells were seeded into 6-, 24-, or 96-well plates in a total volume of $2.0,0.4$, or 0.2 $\mathrm{mL}$, respectively. The amount of seeded cells depended on the growth rate of the individual cell lines and was calculated to achieve a final confluency of $95 \%$ after 72 hours. Before cell seeding, the cell numbers of the cell suspensions were determined by MUSE ${ }^{\circledR}$ Cell Analyzer (MerckMillipore, Billerica, MA, USA).

\section{Toxicity measurements by flow cytometry}

Flow cytometry analysis was performed using a Gallios cytofluorometer (Beckman Coulter, Fullerton, CA, USA). ${ }^{23,24}$ Then, 24 hours after seeding into six-well plates, SPION $^{\text {LA-HSA-Ptx }}$ and free Ptx were added to final concentrations of $0,2.25,9.0$, and $36 \mathrm{nM}$. According to the iron content of the SPION ${ }^{\text {LA-HSA-Ptx }}$ samples $(0.031,0.125$, and $0.5 \mu \mathrm{g} \mathrm{Fe} / \mathrm{mL}$, respectively), we used SPION ${ }^{\mathrm{LA}-\mathrm{HSA}}$ to prepare SPION controls with the same iron content. The negative control was SPION- and Ptx-free; the toxicity control contained 2.0\% dimethyl sulfoxide (DMSO). After treatment, the cells were incubated for another 24 or 48 hours before harvesting and resuspension of the cells in $0.5 \mathrm{~mL}$ PBS. For viability analysis, $50 \mu \mathrm{L}$ aliquots of the cell suspension were incubated with $250 \mu \mathrm{L}$ staining solution for 20 minutes at $4{ }^{\circ} \mathrm{C}(1 \mathrm{~mL}$ staining solution contained $10 \mu \mathrm{g}$ Hoe, $1 \mu \mathrm{L}$ AxV-FITC, and 2.04 $\mu \mathrm{g} \mathrm{DiIC}_{1}(5)$ and $66.6 \mathrm{ng}$ PI in Ringer's solution). Every sample was measured for 60 seconds. For the analysis of DNA degradation and cell cycle, $200 \mu \mathrm{L}$ cell suspensions were fixed by adding $3 \mathrm{~mL}$ of $70 \%(\mathrm{v} / \mathrm{v})$ ice cold ethanol and stored for at least 24 hours at $-20^{\circ} \mathrm{C}$. $^{25}$ Subsequently, the cells were centrifuged ( 5 minutes, $450 \mathrm{~g}$, $24^{\circ} \mathrm{C}$ ), the supernatant was removed, and the cells were washed with PBS before resuspending in $0.5 \mathrm{~mL}$ PBS and $0.5 \mathrm{~mL}$ DNA extraction buffer (192 mL of $0.2 \mathrm{M} \mathrm{Na}_{2} \mathrm{HPO}_{4}$, $8 \mathrm{~mL} 0.1 \%$ Triton X-100 (v/v), $\mathrm{pH} 7.8)$. After additional incubation for 5 minutes at RT, the cells were centrifuged ( 5 minutes, $450 \mathrm{~g}, 24^{\circ} \mathrm{C}$ ), the supernatant was removed, and the cells were resuspended in $0.4 \mathrm{~mL}$ DNA staining solution $(20 \mu \mathrm{g} / \mathrm{mL}$ PI and $200 \mu \mathrm{g} / \mathrm{mL}$ ribonuclease $\mathrm{A}$ in PBS) and incubated in the dark for another 30 minutes at RT. Electronic compensation was used to eliminate bleed through fluorescence. Data analysis was performed with Kaluza software Version 1.2 (Beckman Coulter). All flow cytometry experiments were performed in triplicate in three independent experiments.

\section{IncuCyte ${ }^{\circledR}$ live-cell imaging}

After seeding of cells into 24-well plates, the cells were allowed to grow for another 24 hours before adding SPION ${ }^{\text {LA-HSA-Ptx }}$ and free Ptx to final concentrations of $0,2.25$,

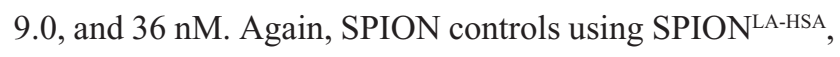
SPION- and Ptx-free negative controls, and toxicity controls containing 2.0\% DMSO were used. Subsequently, the cell culture plates were placed into the live-cell analysis system IncuCyte $^{\circledR}$ (Essen BioScience Ltd., Hertfordshire, UK), and cell confluency was measured every hour for 7 days. The experiments were performed in duplicate in four independent experiments.

\section{Growth experiments with 3D tumor spheroid models} Growth experiments with 3D breast cancer spheroids were used as 3D tumor models to study the impact of Ptx treatment. After seeding of 6,000 cells into 96-well plates coated with $50 \mu \mathrm{L} 2 \%$ agarose, the cells were allowed to form spheroids for 24 hours before adding SPION ${ }^{\text {LA-HSA-Ptx }}$ and free Ptx to a final concentration of $36 \mathrm{nM}$ cell culture

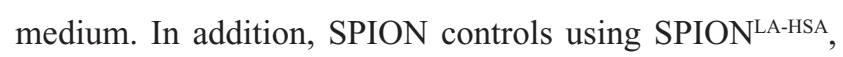
SPION- and Ptx-free negative controls, and toxicity controls containing 2.0\% DMSO were used. The 3D spheroids 
were photographed every 24 hours for 7 days using a Zeiss Axiovert 40 CFL Microscope (Carl Zeiss AG, Oberkochen, Germany). Finally, the 2D-projected tumor areas were measured using the Nikon NIS elements 5.0 software (Tokyo, Japan). The experiments were performed in octuplicate in three independent experiments.

\section{Results}

\section{Production and physiochemical properties of SPIONs}

LA- and HSA-coated iron oxide nanoparticles (SPION ${ }^{\mathrm{LA}-\mathrm{HSA}}$ ) were synthesized by coprecipitation and subsequent in situ coating with LA followed by adsorptive binding of HSA

\section{A}

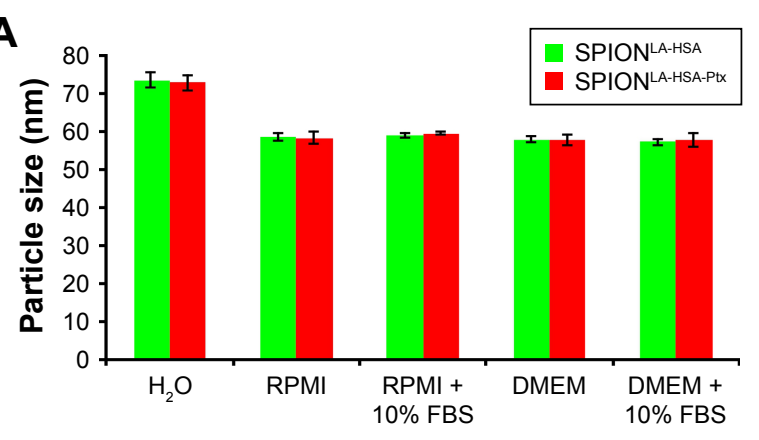

Particle solvent
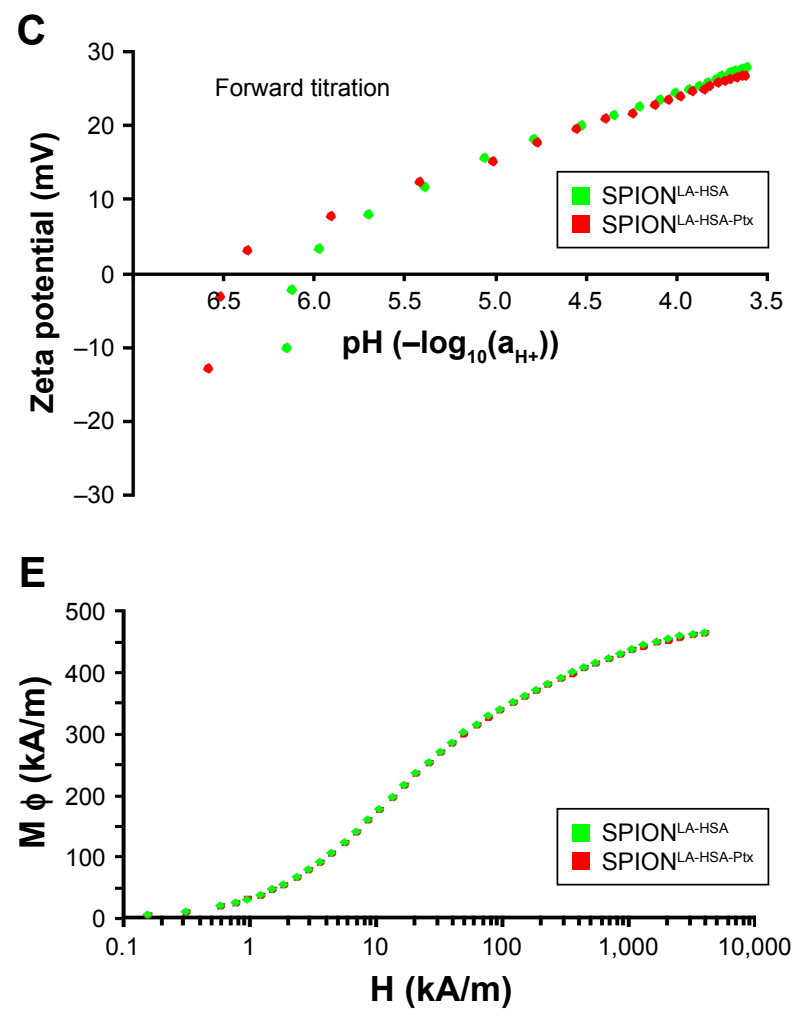

and purified by tangential flow filtration, as described previously. ${ }^{17}$ Ptx was attached to the SPION ${ }^{\text {LA-HSA }}$ particles by adsorption to the HSA protein corona to produce Ptxfunctionalized cytotoxic nanoparticles (SPION ${ }^{\text {LA-HSA-Ptx }}$ ).

Investigation of the hydrodynamic size, measured by DLS in ultrapure water, revealed nearly identical particle diameters of 73.6 and $72.8 \mathrm{~nm}$ for SPION ${ }^{\text {LA-HSA }}$ and SPION ${ }^{\text {LA-HSA-Ptx }}$, respectively (Figures 1A and S1; Table S1). Thus, the adsorption of the small molecules did not increase the water shell, indicating an incorporation of the hydrophobic drug into the drug binding sites of HSA within the corona rather than an attachment onto the HSA protein surface of the particles. ${ }^{26,27}$ As the solvent highly determines the formation of the dynamic

B
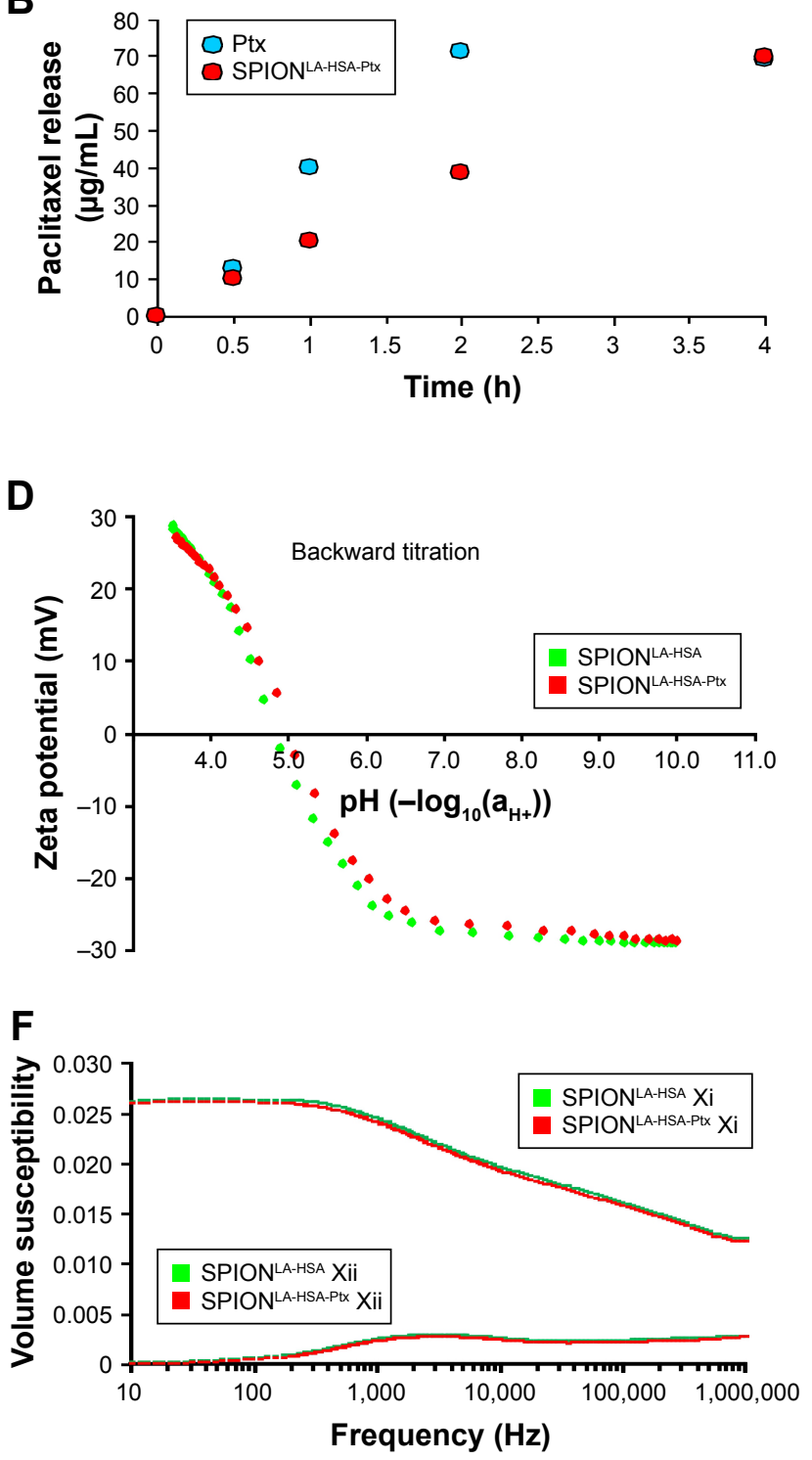

Figure I (Continued) 
G

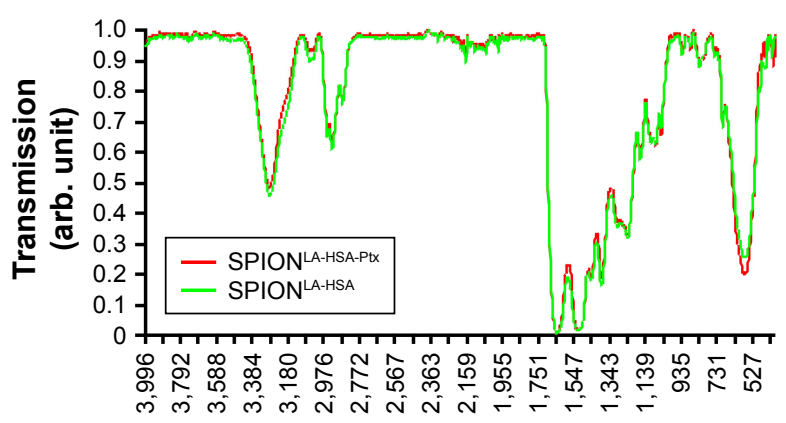

Wavelength $(\mathrm{nm})$
H

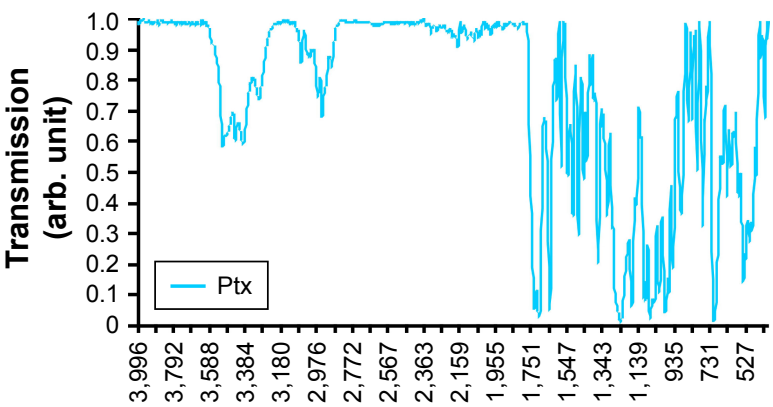

Wavelength (nm)
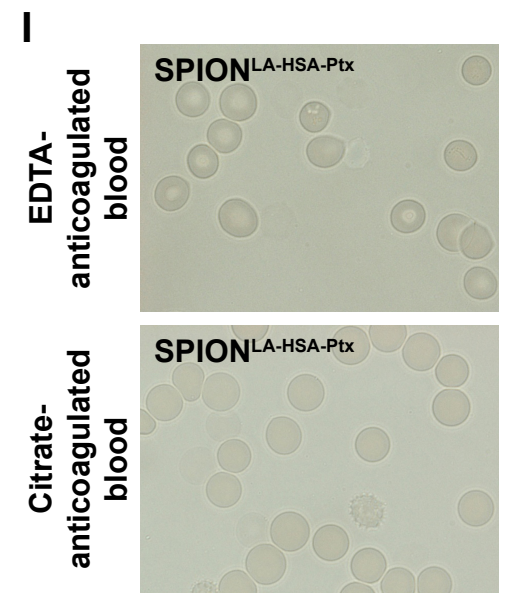
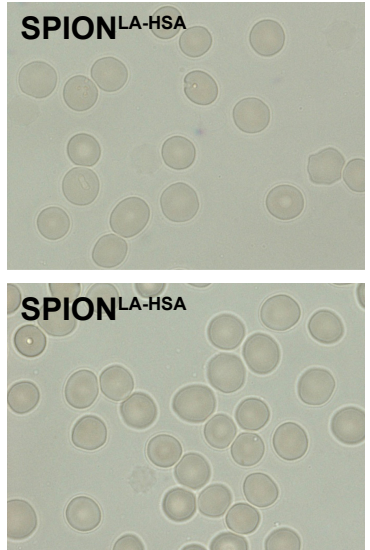
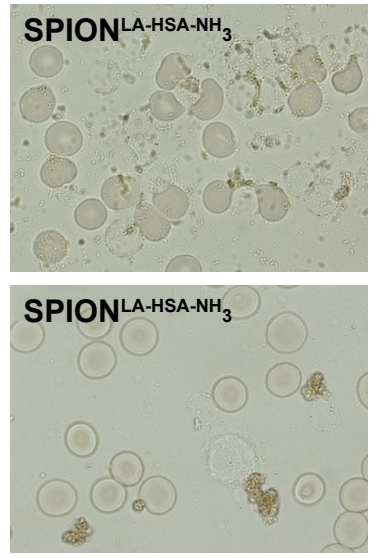
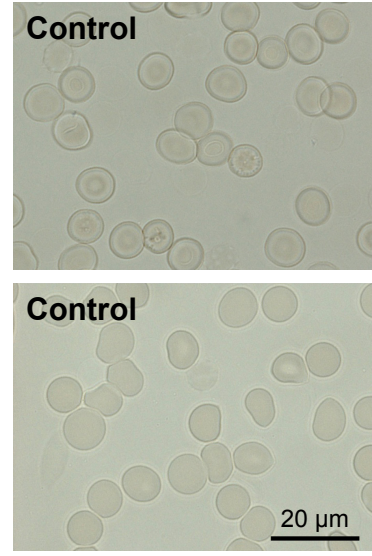

Figure I Physicochemical properties of Ptx-loaded SPIONs.

Notes: (A) Hydrodynamic diameter of Ptx-loaded and unloaded particles in water and different cell culture media. (B) Dialysis-based release kinetics of SPION-adsorbed Ptx compared with free Ptx. (C, D) $\zeta$ potential as a function of $\mathrm{pH}$ in SPION LA-HSA and SPION LA-HSA.Ptx during (C) forward titration and (D) backward titration. (E) Magnetization curves showing the $\mathrm{M}(\mathrm{H})$ data of SPION ${ }^{L A-H S A}$ and SPION ${ }^{\text {LA-HSA-Pxx. }}$ (F) AC susceptibility spectra of SPION ${ }^{\text {LA-HSA }}$ and SPION ${ }^{L A-H S A-P D x}$. (G, H) Fourier transform infrared spectroscopy spectra of (G) SPION ${ }^{\text {LA-HSA }}$, SPION ${ }^{\text {LA-HSA-PAx }}$, and (H) free Ptx. (I) Stability of SPION ${ }^{\text {LA-HSA }}$ and SPION ${ }^{\text {LA-HSA-PPX }}$ in human blood. SPIONs coated with lauric acid and aminated human serum albumin (SPION ${ }^{\text {LA-HSA-NH2 }}$ ) were used as a positive control for nonstable particles. Negative control = corresponding amount of $\mathrm{H}_{2} \mathrm{O}$ instead of water-based ferrofluid. Representative images were recorded using optical bright-field microscopy.

Abbreviations: DMEM, Dulbecco's Modified Eagle's Medium; EDTA, ethylenediaminetetraacetic acid; FBS, fetal bovine serum; H, applied magnetic field; M $\phi$, magnetization; Ptx, paclitaxel; RPMI, Roswell Park Memorial Institute; SPION, superparamagnetic iron oxide nanoparticles; SPION ${ }^{\text {LA-HSA }}$, lauric acid- and human serum albumin-coated

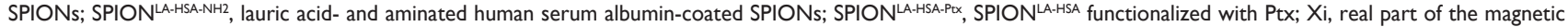
susceptibility; Xii, imaginary part of the magnetic susceptibility.

corona which is known to influence particle stability, uptake, and toxicity, we investigated the size of the SPIONs in more complex fluids such as different cell culture media. ${ }^{28,29}$ The presence of FBS-free RPMI or DMEM led to a reduction of the SPION ${ }^{\text {LA-HSA }}$ and SPION ${ }^{\text {LA-HSA-Ptx }}$ particle sizes to $\sim 58 \mathrm{~nm}$. The size reduction in cell culture medium compared with $\mathrm{H}_{2} \mathrm{O}$ demonstrated a very high conductivity due to increased ions and protein concentration in medium, leading to a suppression of the electrical double layer and thus to a smaller hydrodynamic diameter. ${ }^{30}$ Notably, the particle size measured in the medium did not significantly change in the presence of medium supplemented with 10\% FBS (Figure S1). Finally, measurements of the PDI revealed values less than 0.2 for all particles diluted in $\mathrm{H}_{2} \mathrm{O}$ and FBS-free RPMI and DMEM cell culture media (Table S1). Although the particle size distribution did not broaden, the PDI of SPIONs in the presence of $10 \%$ FBS increased up to 0.26 . This effect is due to an additional small peak in the size of $7.3 \mathrm{~nm}$, originating from FBS (Figure S1). Finally, the samples were stored at $4^{\circ} \mathrm{C}$ and measured again after 7 days. The data revealed no sign of aggregation or agglomeration (Figure S1; Table S1). Thus, both Ptx-loaded and unloaded nanoparticles were highly stable without any tendency of agglomeration.

For an efficient MDT approach, Ptx needs to remain associated with the particles as long as needed to accumulate at the tumor site. Subsequently, the drug should easily diffuse from the particles to enable a fast entrance into the cell and the nucleus to maximize its cytotoxic effects. To investigate the release profile of Ptx from the particles, we performed a dialysis-based drug release experiment (Figure 1B). 
SPION ${ }^{\text {LA-HSA-Ptx }}$ demonstrated an acceptable release profile during the first 2 hours, showing a $50 \%$ inhibition of the Ptx diffusion compared with free Ptx. This relatively long binding capacity for a simply adsorbed substance is due to the high affinity binding of Ptx to $\mathrm{HSA}^{31}$ and qualifies MDT as this treatment usually takes $<20$ minutes. ${ }^{12,31}$

Figure $1 \mathrm{C}$ and $\mathrm{D}$ shows the $\zeta$ potential as a function of $\mathrm{pH}$. The aqueous $\zeta$ potential of freshly produced SPION ${ }^{\text {LA-HSA-Ptx }}$ was $-13.1 \mathrm{mV}$ at $\mathrm{pH} 6.57$ and slightly more negative than that of the Ptx-free SPION ${ }^{\text {LA-HSA }}$ with $-10.3 \mathrm{mV}$ at $\mathrm{pH}$ 6.14. During titration to lower $\mathrm{pH}$ values, the IEP was reached at $\mathrm{pH} \sim 6.4$ and $\sim 6.1$ for SPION ${ }^{\text {LA-HSA-Ptx }}$ and SPION ${ }^{\mathrm{LA}-\mathrm{HSA}}$, respectively. At very low $\mathrm{pH}(\mathrm{pH} 3.6)$, the $\zeta$ potential reached a relatively high positive charge with $\sim 30 \mathrm{mV}$. Subsequent titration to higher $\mathrm{pH}$ values revealed a very similar IEP for both particles at $\mathrm{pH} \sim 5.0$, which remained constant during additional up-titration and down-titration, indicating a similar dynamic ion exchange for both systems and a negligible effect of the adsorbed Ptx in the protein corona.

Magnetic properties are one of the most important requirements for the magnetically based delivery of drugbound SPIONs to the tumor site. Therefore, magnetization curves of SPION ${ }^{\text {LA-HSA-Ptx }}$ and SPION ${ }^{\text {LA-HSA }}$ were determined using a commercial superconducting quantum interference device magnetometer (Figure 1E). Dynamic magnetic properties were measured applying ACS (Figure 1F). At $5 \mathrm{~T}$, the samples showed a magnetization of $\sim 460 \pm 15 \mathrm{kA} / \mathrm{m}$, which is close to the bulk value of magnetite of $480 \mathrm{kA} / \mathrm{m} .{ }^{32}$ This provides evidence of the fact that the crystallographic phase of the magnetic nanoparticle is almost pure magnetite. The spectrum of the imaginary part shows a maximum caused by the Brownian relaxation of blocked nanoparticles at around $3 \mathrm{kHz}$ and a shoulder at high frequencies, which is caused by Néel relaxation-dominated particles with a wide distribution of time constants. The imaginary and real parts of the susceptibility measurements show almost no differences with respect to functionalization with Ptx. Thus, the hydrodynamic diameter, which was determined to be $d_{h} \approx 50 \mathrm{~nm}$ from the frequency of the Brownian maximum in the imaginary part, is not significantly changed by the binding of Ptx. It should be noted that this value may be erroneous as both the coexistence of Brownian and Néel relaxation processes via the generalized Debye model, and the inclusion of correlations between core and hydrodynamic diameters may cause significant deviations from the criterion $\omega \tau_{\mathrm{B}}=1$ applied to calculate the hydrodynamic diameter from the peak position in the imaginary part. ${ }^{33}$ The appearance of the Brownian maximum in the imaginary part indicates that at least particles relaxing via Brownian relaxation did not bind any Ptx or the binding energy is as weak as it has no influence on the particles' volume friction. Nevertheless, measurements enable the conclusion that Ptx functionalization does not impair the magnetic behavior of the SPIONs. Furthermore, a comparably wide size distribution was observed, which is reflected in a distinct superposition of real and imaginary parts of the susceptibility. These results indicate an effective influence of an external magnet for possible drug targeting purposes.

An established method for analyzing the chemical structure of the coated iron oxide nanoparticles is FTIR (Figure $1 \mathrm{G}$ and $\mathrm{H}$ ). The measurements covered the wavelength range from 4,000 to $400 \mathrm{~cm}^{-1}$. All nanoparticles featured a strong peak at around $570 \mathrm{~cm}^{-1}$, related to $\mathrm{Fe}-\mathrm{O}$ surface vibrations of the iron oxide core. ${ }^{34}$ The characteristic infrared absorption bands and their assignments for HSA are $3,285 \mathrm{~cm}^{-1}$ (amide A, N-H stretching), 2,928 $\mathrm{cm}^{-1}$ (C-H stretching), $1,642 \mathrm{~cm}^{-1}$ (amide I, $\mathrm{C}=\mathrm{O}$ stretching), 1,513 $\mathrm{cm}^{-1}$ (amide II, $\mathrm{C}-\mathrm{N}$ stretching and $\mathrm{N}-\mathrm{H}$ bending $), 1,451 \mathrm{~cm}^{-1}\left(\mathrm{C}-\mathrm{H}_{2}\right.$ bending), 1,388 $\mathrm{cm}^{-1}$ (carboxylate), and 1,299-1,240 $\mathrm{cm}^{-1}$ (amide III, $\mathrm{C}-\mathrm{N}$ stretching and $\mathrm{N}-\mathrm{H}$ bending). ${ }^{35}$ The bands between 1,500 and $1,000 \mathrm{~cm}^{-1}$ are in the "fingerprint" region of native HSA. ${ }^{36}$ Due to the low mass ratio of Ptx in relation to the HSA-coated particles and the highly probable infiltration of Ptx into the protein corona, FTIR measurements did not reveal the presence of Ptx on the particles. However, the release experiments clearly demonstrate a successful adsorption, at least for the first few hours after dilution of the particles. Finally, the stability of the nanoparticles was further investigated in EDTA-anticoagulated and citrate-anticoagulated human blood at a microscopic level (Figure 1I). SPION ${ }^{\text {LA-HSA }}$ and SPION ${ }^{\text {LA-HSA-Ptx }}$ were both stable and did not show any sign of agglomeration in blood. Moreover, the morphology of erythrocytes was indistinguishable in those samples. In contrast, nonstable SPION ${ }^{\mathrm{LA}-\mathrm{HSA}-\mathrm{NH} 2}$, containing LA and aminated HSA, showed different degrees of agglomeration in EDTA- and citrate-anticoagulated blood samples. These assays clearly showed the good biostability of the particle systems used in this study and indicated their possible usage for in vivo experiments. Table $\mathrm{S} 1$ shows the summary of the main physicochemical properties.

\section{Cellular toxicity of Ptx-functionalized SPIONs}

Breast cancer has a heterogeneous molecular nature and can be characterized based on the protein expression of estrogen receptor alpha $(\mathrm{ER} \alpha)$, progesterone receptor $(\mathrm{PR})$, and human epidermal growth factor receptor 2 (HER2) and grouped 
into, ie, luminal A, luminal B, and basal-like types. ${ }^{16,37}$ Due to this heterogeneity, it is necessary to compare the effects of new drugs or drug carriers such as SPION ${ }^{\text {LA-HSA-Ptx }}$ in different breast cancer cells with clinically used pure cytostatic drugs to evaluate their efficiency or their advantages within new application techniques. Thus, the cell lines used in this study belong to different subtypes: MCF-7 and T-47D are grouped into luminal A but differ in their growth rate; BT-474 is a luminal B subtype, and MDA-MB-231 belongs to the triple-negative group. ${ }^{37,38}$

The biological effects of Ptx-functionalized particles were investigated in a time-, concentration-, and cell typedependent manner, and compared with the impact of Ptx-free particles and sole Ptx. To avoid the interference of standard toxicology assays based on the spectroscopic methods by the inherent light absorption of iron oxide nanoparticles, ${ }^{39,40}$ we used multiparameter flow cytometry, ${ }^{23,41}$ which enables an interference-free analysis of thousands of single cells to determine the cytotoxicity of SPION ${ }^{\mathrm{LA}-\mathrm{HSA}-\mathrm{Ptx}}$ and free Ptx (Figure S2, Figure 2 and Table S2)..$^{23,39-41}$ After 24- and 48-hours exposures, we analyzed the impact of $0,2.25,9.0$, and $36 \mathrm{nM}$ particle-bound and free Ptx on viability, apoptosis, necrosis, mitochondrial membrane potential, cell cycle, and DNA degradation. Due to the huge amount of generated data, the 24-hour results were transferred to the Supplementary materials (Figure S2).

The differentiation between viable, apoptotic, and necrotic cells was achieved by $\mathrm{AxV}$ and PI staining (Figure 2, first column). All cell lines showed a dose-dependent response to SPION ${ }^{\text {LA-HSA-Ptx }}$ and free Ptx. While the lowest concentration values of free and particle-bound Ptx were comparable with the negative controls, the highest concentration of free Ptx reduced the viability of BT-474, MCF-7, MDA-MB-231, and T-47D cells to $38 \%, 46 \%, 18 \%$, and $17 \%$, and SPION ${ }^{\mathrm{LA}-H S A-P t x}$ incubation led to slightly higher remaining viability of $58 \%$, 55\%, 28\%, and 28\%. Moreover, MDA-MB-231 and T-47D were generally more sensitive to Ptx, regardless of whether it was particle-bound or free, compared with BT-474 and MCF-7 cells. These differences seem to be drug-specific as the positive control using $2 \%$ DMSO led to a different
A

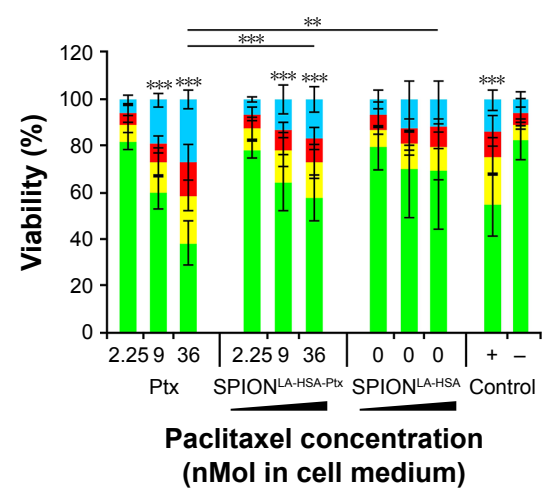

B

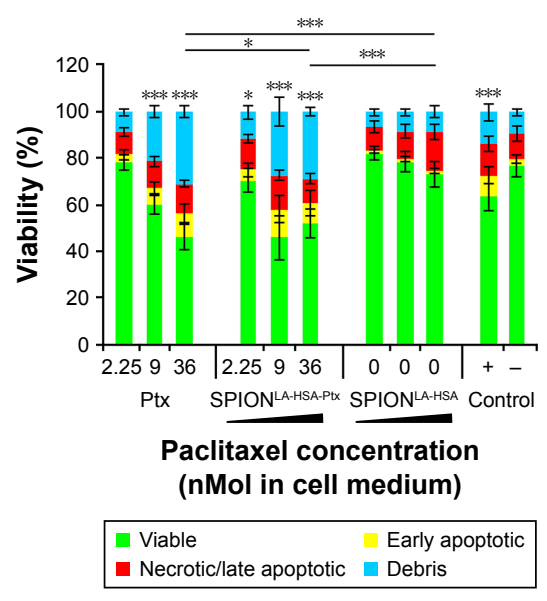

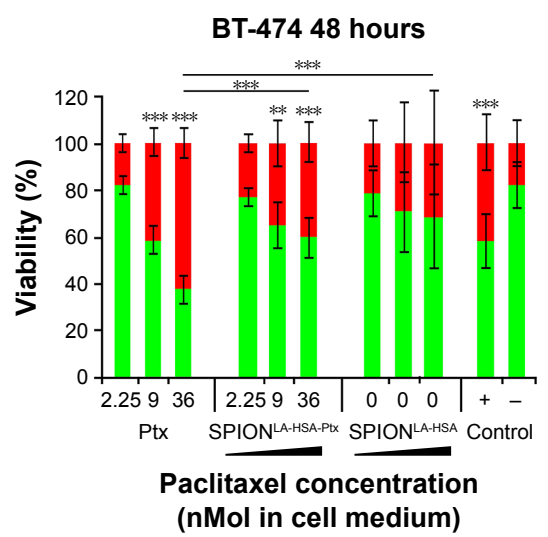

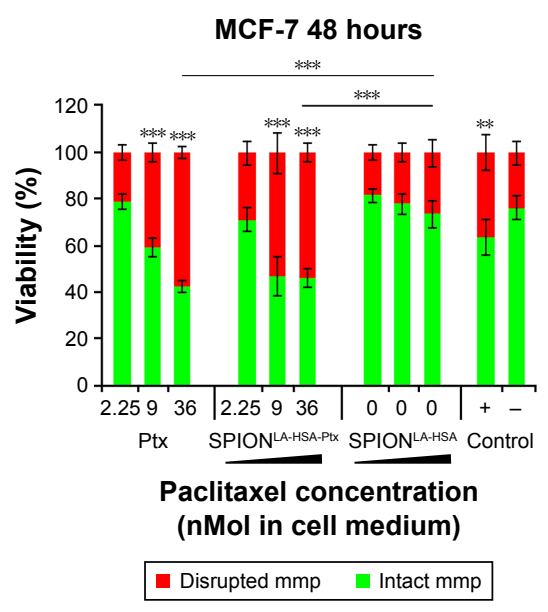

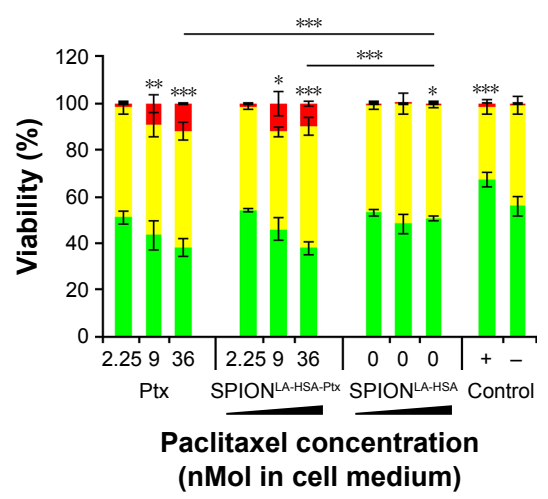

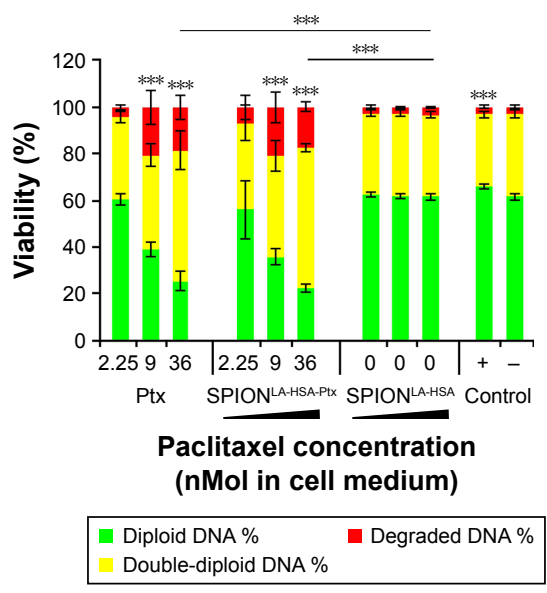

Figure 2 (Continued) 
C

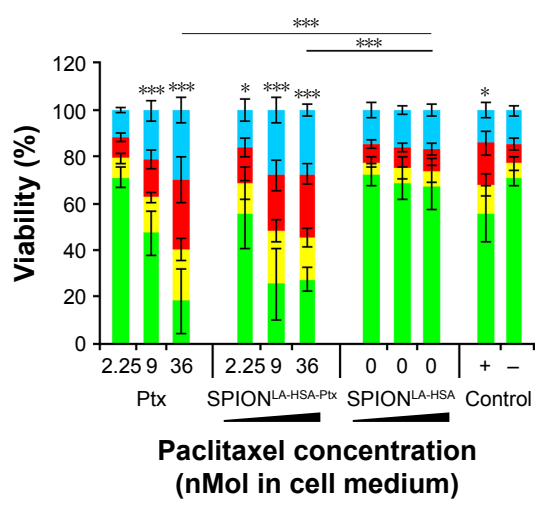

D

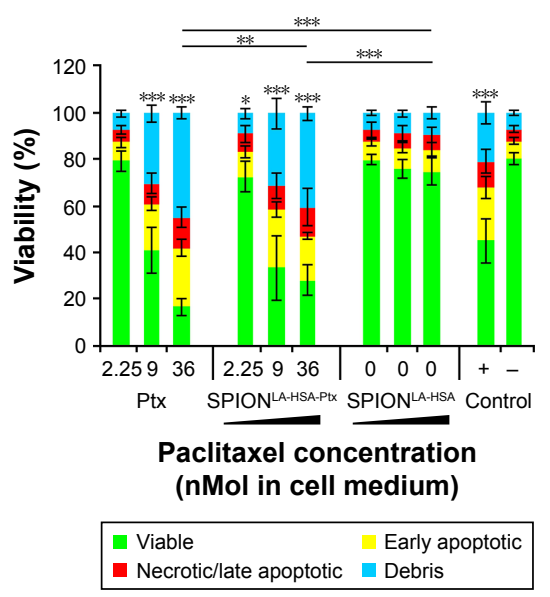

MDA-MB-231 48 hours

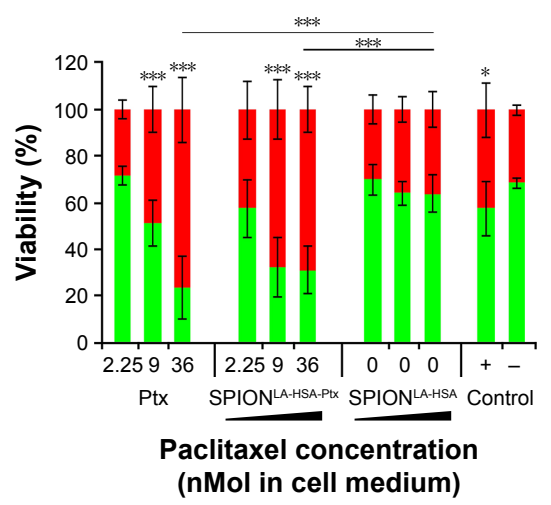

T-47D 48 hours

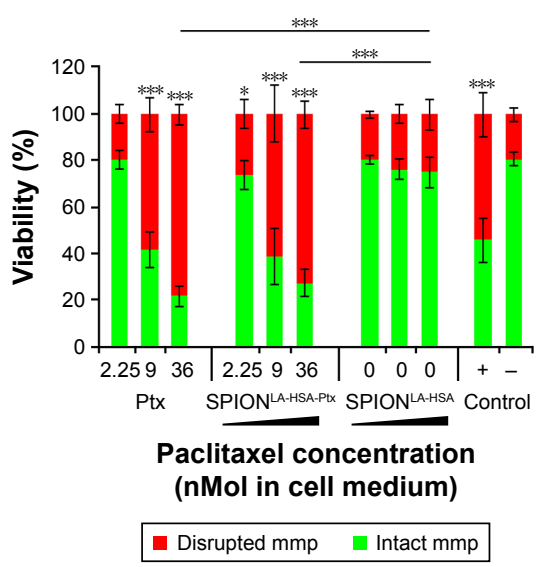

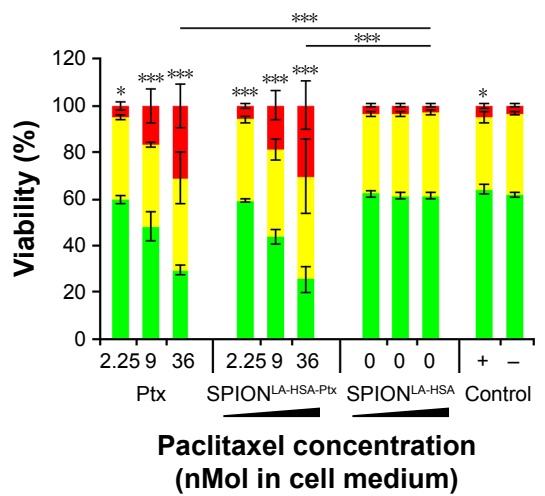

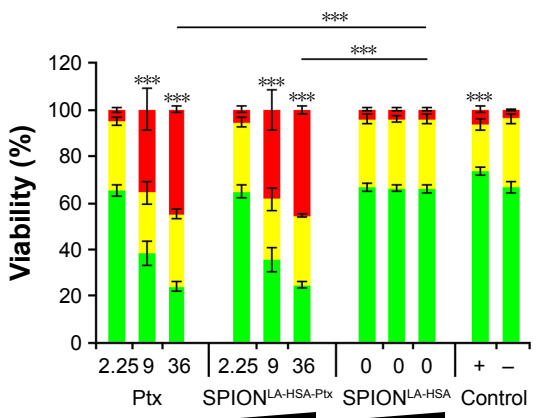

Paclitaxel concentration ( $\mathrm{nMol}$ in cell medium)

\begin{tabular}{|l|}
\hline Diploid DNA \% \\
Double-diploid DNA \%
\end{tabular}

Figure 2 Viability of breast cancer cells 48 hours after Ptx treatment.

Notes: (A) BT-474, (B) MCF-7, (C) MDA-MB-23I, and (D) T-47D cells were incubated for 48 hours with increasing amounts of free Ptx, SPIONLA-HSA-Pxx, and SPIONLA-HSA and analyzed by multiparameter flow cytometry. Viability was determined by AxV-FITC and PI staining (first column), yielding the percentage of viable (Ax- PI-), apoptotic $(\mathrm{Ax}+\mathrm{PI}-)$, and necrotic $(\mathrm{PI}+)$ cells. The status of the mitochondrial membrane potential was analyzed by DilC $\mathrm{C}_{1}(5)$ staining and distinguishes cells with intact $\left(\mathrm{DilC} \mathrm{C}_{1}(5)\right.$ positive) and depolarized (DilC $(5)$ negative) membranes (middle column). DNA degradation and cell cycle were determined by PIT staining and showed the amount of degraded DNA, diploid DNA (GI phase), and double-diploid DNA (synthesis/G2 phase; last column). Positive controls contain $2 \%$ DMSO, and negative controls represent the corresponding amount of solvent instead of drug or ferrofluid. Data are expressed as the mean \pm SD ( $n=3$ with technical triplicate). Statistical significance of viability, intact membrane potential, and diploid DNA content between control and samples are indicated with $* P<0.0$ I, $* * P<0.00$ I, and $* * * P<0.000$ I, and were calculated via Student's t-test analysis.

Abbreviations: AxV, Annexin A5; DilC, (5), I,I',3,3,3',3'-hexamethylindodicarbocyanine iodide; DMSO, dimethyl sulfoxide; FITC, fluorescein isothiocyanate; PI, propidium iodide; PIT, propidium iodide-Triton X-100; Ptx, paclitaxel; SPION, superparamagnetic iron oxide nanoparticles; SPION ${ }^{\text {LA-HSA }}$, lauric acid- and human serum albumin-coated SPIONs; SPION ${ }^{\text {LA-HSA-Pxx }}$ SPION LA-HSA functionalized with Ptx.

pattern, showing very similar viabilities between BT-474, MCF-7, and MDA-MB-231 (55\%, 64\%, and 56\%) and a stronger decrease to $45 \%$ only in T-47D cells.

Comparable results were achieved by DiIC $_{1}(5)$ staining, where the disintegration of the mitochondrial membrane potential, an event during early apoptosis, correlates with a decreased fluorescence intensity (Figure 2, second column; Table S2). ${ }^{23}$ With free Ptx, the amounts of BT-474, MCF-7, MDA-MB-231, and T-47D cells containing a disturbed mitochondrial membrane potential increased to $62 \%, 57 \%$, $76 \%$, and $78 \%$ at the highest Ptx concentration, which were generally slightly higher than achieved with SPION ${ }^{\text {LA-HSA-Ptx }}$
(40\%, 53\%, 69\%, and 72\%, respectively). Similar to the viability assay with $\mathrm{AxV}$ and PI, MDA-MB-231 and T-47D cells were more sensitive to free Ptx and SPION ${ }^{\mathrm{LA}-H S A-P t x}$ than BT-474 and MCF-7 cells. Again, this did not coincide with the results achieved in the presence of $2 \%$ DMSO, showing similar results for BT-474, MCF-7, and MDA-MB-231, and increased toxicity for T-47D (42\%, 36\%, 42\%, and 54\%), indicating a different mode of action for Ptx and DMSO already during the early events of apoptosis.

Finally, PI/Triton X-100 staining of cells incubated with free Ptx and SPION ${ }^{\text {LA-HSA-Ptx }}$ was performed to examine the cell cycle stage and DNA degradation (Figure 2, third column; 
Table S2). ${ }^{25}$ The amount of double-diploid DNA was highest in untreated BT-474 cells with $43 \%$ followed by MCF-7 and MDA-MB-231 with 35\% each and T-47D with 29\%. In the presence of Ptx or SPION ${ }^{\mathrm{LA}-H S A-P t x}$, all cell lines responded with a strong dosage-dependent decrease of diploid DNA and an increase of degraded and double-diploid DNA, indicating an emerging cell cycle arrest in $G_{2}$ phase. Notably, the cell-specific impact on cell cycle and DNA degradation by Ptx or SPION ${ }^{\text {LA-HSA-Ptx }}$ treatment was very similar. However, there were apparent differences in the amount of diploid, double-diploid and degraded DNA between the single cell lines (Table S2), indicating a dose- and cell-dependent toxicity of Ptx, independent of its use as a free agent or bound to SPIONs.

In summary, the achieved data revealed very similar cytotoxic effects of free Ptx and SPION ${ }^{\text {LA-HSA-Ptx }}$, indicating the same mode of action dismissing the possibility of structural alteration of the molecule after binding to the particles or masking effects after binding into the hydrophobic binding sites of HSA. Moreover, the impact of the carrier particles SPION ${ }^{\mathrm{LA}-\mathrm{HSA}}$ was very low, confirming recently published data about the cytotoxicity and cellular uptake of SPION ${ }^{\text {LA-HSA }}$ using identical breast cancer cells as in this study. ${ }^{21}$

\section{Live-cell imaging of Ptx-treated cells in 2D cell culture}

Interestingly, the cytotoxic impact of free Ptx and SPION ${ }^{\text {LA-HSA-Ptx }}$ and their influence on the cell cycle status after 48 hours were very similar to the data achieved after 24 hours (Figure S2). Thus, during the first 48 hours, there seems to be a balance between cell growth and toxicity. As the prolongation of the exposure time strongly increases the efficiency of Ptx, ${ }^{42}$ we investigated the breast cancer cell growth kinetics during the treatment with free Ptx and SPION ${ }^{\text {LA-HSA-Ptx }}$ using the IncuCyte ${ }^{\circledR}$ live-cell imaging system (Figure 3). ${ }^{42}$ Again, we used a negative control, containing the corresponding volume of solvent without drug or SPIONs, a positive control with $2 \%$ DMSO, and SPION
A
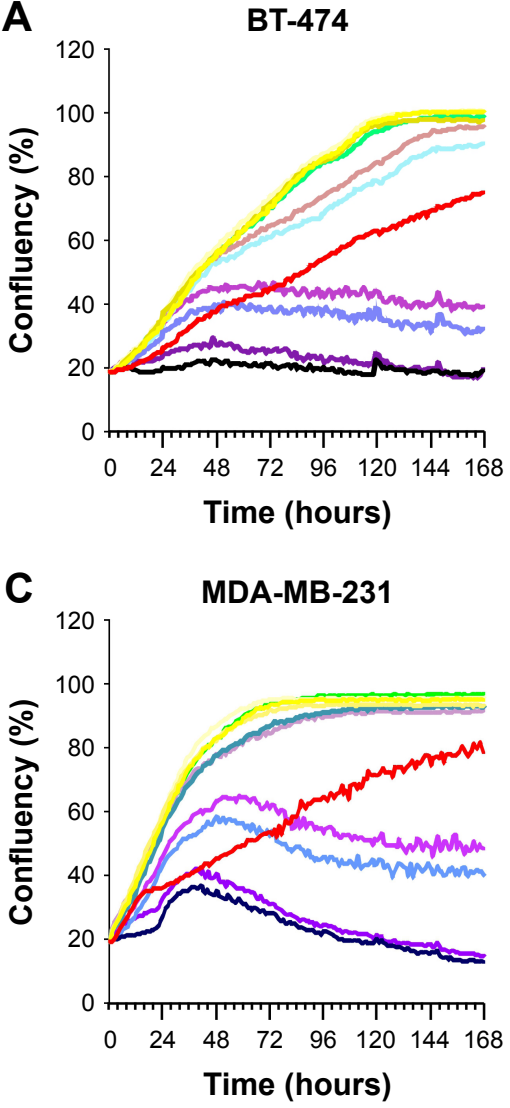

B

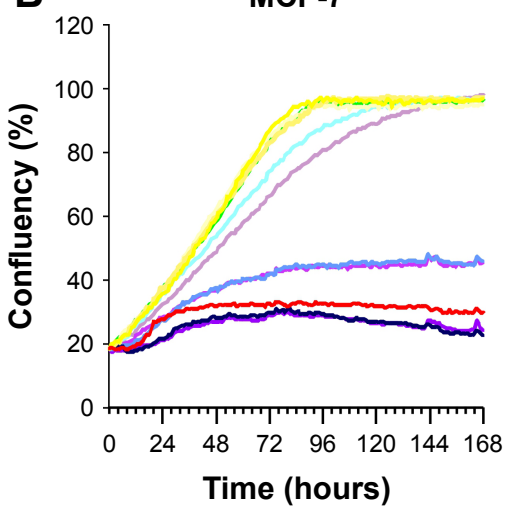

D

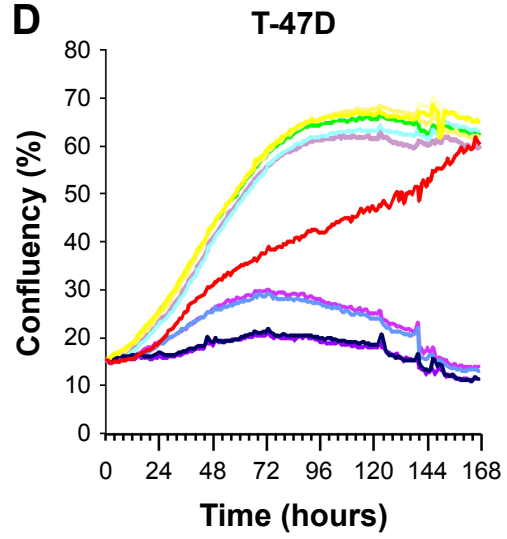

\begin{tabular}{|c|}
\hline 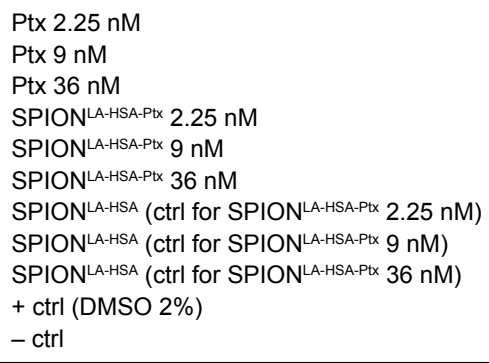 \\
\hline
\end{tabular}

Figure 3 Growth kinetics of different cell lines in the presence of Ptx and SPION ${ }^{\text {LA-HSA.PLx }}$

Notes: (A) BT-474, (B) MCF-7, (C) MDA-MB-23I, and (D) T-47D cells were incubated for 7 days with increasing amounts of free Ptx, SPIONLA-HSA-Ptx, and SPIONLA-HSA. Cellular confluency was determined hourly using the IncuCyte ${ }^{\circledR}$ live-cell imaging system, providing growth kinetics for all different samples. Positive controls contained $2 \%$ DMSO, and negative controls contained the corresponding amount of solvent instead of drug or ferrofluid. Data are expressed as the mean \pm SD ( $=4$ with technical triplicate).

Abbreviations: Ctrl, control; DMSO, dimethyl sulfoxide; Ptx, paclitaxel; SPION, superparamagnetic iron oxide nanoparticles; SPION ${ }^{\text {LA-HSA }}$, lauric acid- and human serum albumin-coated SPIONs; SPION ${ }^{\text {LA-HSA-PQx }}$, SPION ${ }^{\text {LA-HSA }}$ functionalized with Ptx. 
controls containing the respective amount of drug-free SPIONs. The cellular confluency within the samples was calculated from the images taken hourly for 7 days. Notably, due to experimental prerequisites, the long-time experiments were performed without media change, resulting in a slow cell-dependent consumption of available nutrients. While BT-474, MCF-7, and MDA-MB-231 reached a stable confluency of $\sim 100 \%, T-47 \mathrm{D}$ cells, most likely due to nutrient deficiency, only got $<70 \%$ confluency followed by a gradual decrease in cell numbers.

The growth curves of the negative controls and the SPION ${ }^{\mathrm{LA}-\mathrm{HSA}}$ carriers were almost identical, confirming the good biocompatibility of the carrier particles as published recently. ${ }^{17,21}$ In contrast, treatment with free Ptx and SPION ${ }^{\text {LA-HSA-Ptx }}$ resulted in a clearly dose-dependent growth reduction, already seen in the presence of the lowest Ptx concentration of $2.25 \mathrm{nM}$. At $9.0 \mathrm{nM}$, the growth rate strongly decreased producing a low maximal confluency plateau (BT-474<47\%, MCF-7 <46\%, MDA-MB- $231<65 \%$, and T-47D $<29 \%$ ) followed by a cell-dependent decline, indicating cell death and detachment from the plastic surface of the cell culture dishes. The most crucial effects were reached with $36 \mathrm{nM}$ particle-bound and free Ptx with a significantly faster growth inhibition, a much lower confluency rate, and finally a stronger detachment of the normally adherent cells. Thus, cells do not survive long-time treatment with Ptx, despite initial differences in the Ptx-dependent response of the examined breast cancer cells. Notably, the concentration-dependent kinetics, achieved with sole Ptx-

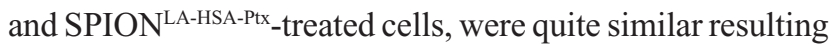
in concentration-dependent paired kinetic curves (Figure 3).

\section{Ptx-related effects on 3D breast cancer tumor models}

The properties of tumors are only partially reflected by $2 \mathrm{D}$ cell cultures. In contrast, 3D tumor models are considered to be clearly superior to mimic the tumor physiology and the effects of therapeutically relevant pathophysiological gradients compared to monolayer-based models. ${ }^{43-45}$ Hence, to confirm the achieved $2 \mathrm{D}$ cell culture results in $3 \mathrm{D}$ cell culture, we established multicellular breast cancer tumor models with BT-474, MCF-7, MDA-MB-231, and T-47D cells (Figure 4). The tumor models were generated by seeding 6,000 cells on agarose-coated cell culture wells. After 24 hours ( 0 hour posttreatment), cell association led to the formation of distinct cell-specific spheroids, which were treated with free Ptx or SPION ${ }^{\text {LA-HSA-Ptx }}$, containing $36 \mathrm{nM}$ Ptx each for at least 7 days. For comparison, we used negative controls, positive controls with $2 \%$ DMSO, and SPION controls containing the respective amount of drug-free SPIONs. Bright field pictures taken every 24 hours enabled the quantification of the spheroid diameter and thus the determination of the growth kinetics. Interestingly, the spheroid size, formation, and morphology differed in all cell lines.

The MCF-7 spheroids were rather inhomogeneous, and the morphology between the spheroids differed stronger than spheroids made from BT-474, MDA-MB-231, and T-47D cells. In addition, all MCF-7 spheroids started to shrink and became more compact, with only slight differences between control and of Ptx-treated spheroids. As reported earlier, due to the inhomogeneity and behavior of MCF-7 cells, the MCF-7 spheroids cannot be recommended as an optimal 3D model for investigating the cytotoxicity or possible cell resistance of anticancer drugs. ${ }^{46}$ BT-474 cells
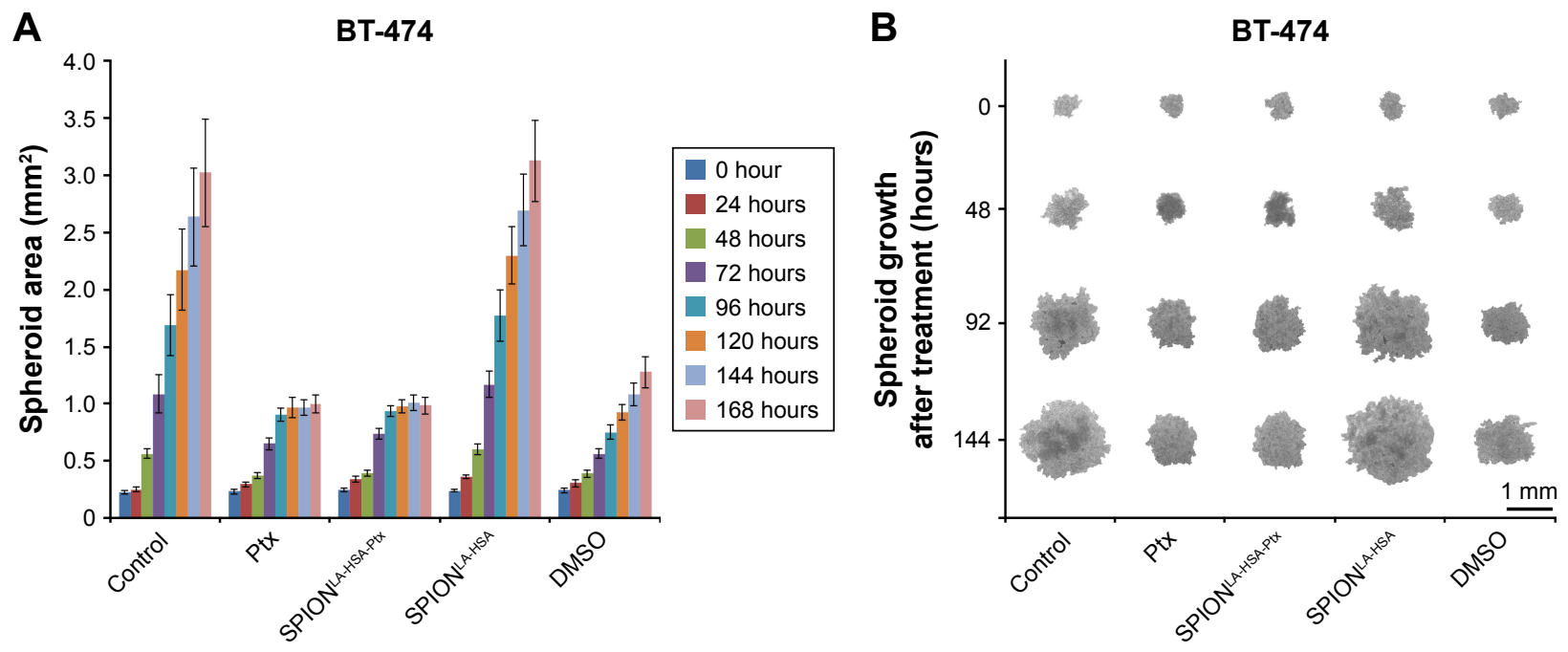

Figure 4 (Continued) 

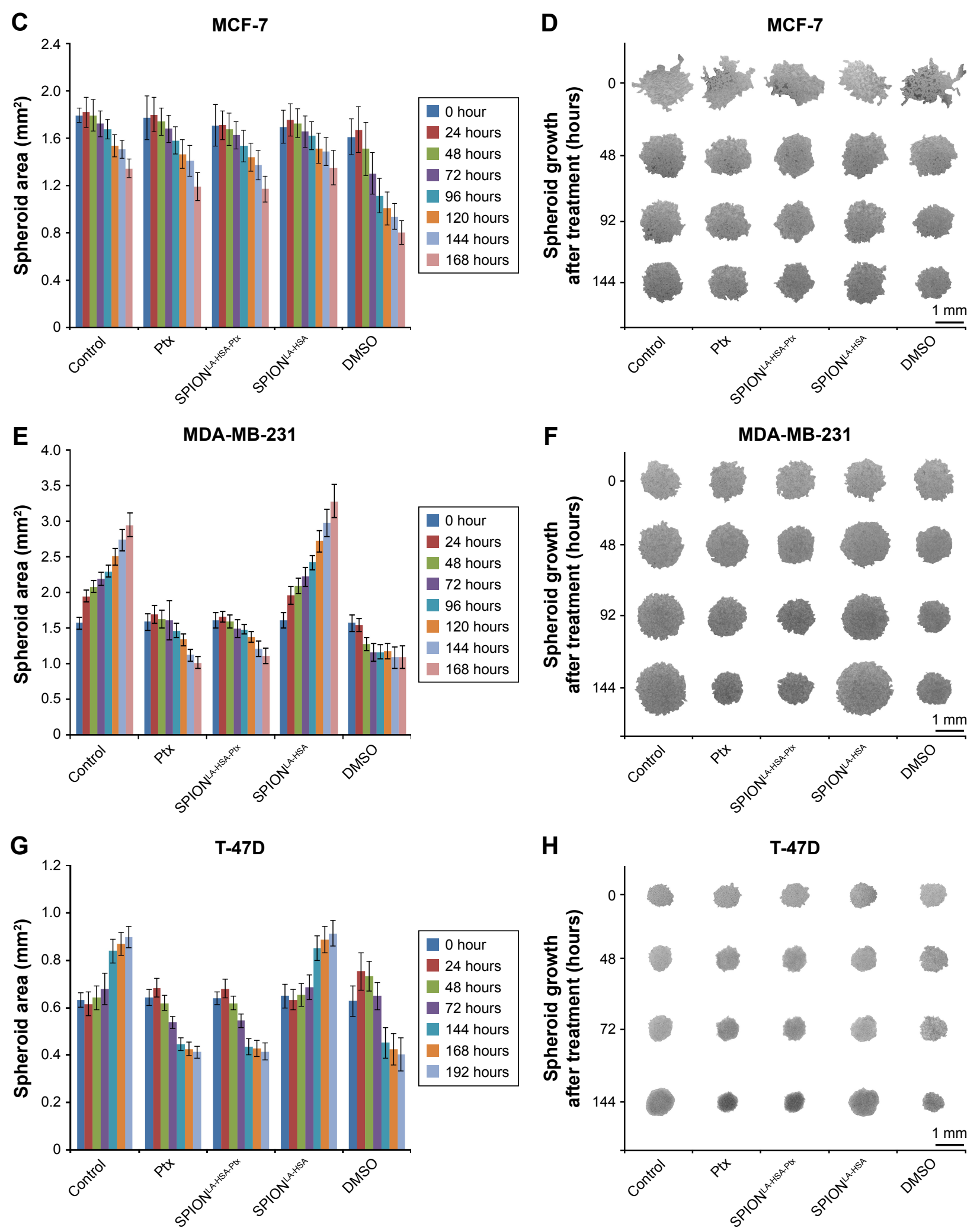

Figure 4 Effects of SPION ${ }^{L A-H S A-P t x}$ and Ptx on three-dimensional cell clusters.

Notes: (A, B) BT-474, (C, D) MCF-7, (E, F) MDA-MB-23I, and (G, H) T-47D spheroids were treated with $36 \mathrm{nM}$ free Ptx or particle-bound Ptx (SPION LA-HSA-Ptx). In addition, a SPION ${ }^{\text {LA-HSA }}$ carrier control, a SPION- and Ptx-free negative control, and positive toxicity control containing $2 \%$ DMSO were utilized. The first column displays the projected two-dimensional area during the treatment. The second column shows representative pictures of the spheroids during the first I44 hours after treatment. Abbreviations: DMSO, dimethyl sulfoxide; Ptx, paclitaxel; SPION, superparamagnetic iron oxide nanoparticles; SPION ${ }^{\text {LA-HSA }}$, lauric acid- and human serum albumin-coated SPIONs; SPION LA-HSA-Ptx, SPION ${ }^{\text {LA-HSA }}$ functionalized with Ptx. 
initially formed the smallest spheroids with $0.23 \mathrm{~mm}^{2}$ (the given area is always a $2 \mathrm{D}$ projection of the spheroids). The negative and SPION ${ }^{\mathrm{LA}-\mathrm{HSA}}$ controls grew very fast, reaching a size of $\sim 3.0 \mathrm{~mm}^{2}$ after 168 hours, whereas, during the first 120 hours, free Ptx and SPION ${ }^{\text {LA-HSA-Ptx }}$ led to strong growth inhibition and cell death, resulting in a final spheroid size of $\sim 1.0 \mathrm{~mm}^{2}$. Similarly, the fast-growing MDA-MB-231 and the slower growing T-47D cells produced spheroids which were strongly affected by free Ptx and SPION ${ }^{\text {LA-HSA-Ptx }}$, resulting in a substantial decrease between $65 \%$ and $70 \%$ of the original size and finally cell death.

\section{Discussion}

To analyze the cellular effects of new drugs or drugs bound to specific carriers such as nanoparticles, it is important to utilize different relevant cell types. In this study, we developed Ptx-functionalized particles for future applications in MDT of breast cancer. Clinically, breast cancer is graded according to histological type, tumor grade, and markers such as HER2, ER, and PR. ${ }^{15}$ According to their molecular characteristics, they can be classified into different subtypes, such as luminal A, luminal B, and basal-like. Due to the highly heterogeneous nature of breast cancer, we chose four different cell lines: BT-474, MCF-7, MDA-MB-231, and T-47D. MCF-7 and T-47D belong to the luminal A class, expressing ER and PR but not HER2 receptors. Luminal A tumor patients principally have the longest survival rates. ${ }^{47}$ However, MCF-7 cells overexpress Ki-67, an antigen that marks fast proliferating cells and is associated with a poorer prognosis, while T-47D usually shows a low Ki-67 expression. ${ }^{16,47,48}$ BT-474 belongs to the luminal B group and is triple positive for ER, PR, and HER2 receptors. Thus, BT-474 represents tumors of patients with an extremely low 5-year survival rate. ${ }^{47}$ MDA-MB-231 is triple negative for ER, PR, and HER2 receptors, and belongs to the basallike subtype, a cancer class with an intermediate 5-year survival rate. ${ }^{47}$

In this study, we produced and investigated the effects of Ptx-functionalized SPIONs and found several cell type- as well as time- and concentration-dependent effects between free Ptx and SPION ${ }^{\text {LA-HSA-Ptx }}$ on the four distinct breast cancer cell lines. Notably, there were only slight differences in the cytotoxic effects between free Ptx and particle-bound Ptx. The underlying cause is most likely the relatively fast release of adsorbed Ptx from the particle carrier (Figure 1B). This feature is beneficial for effective MDT, as the drug only needs to stay conjugated to the particles until the magnetically based accumulation of the particle system at the tumor site is completed. ${ }^{9}$ Other approaches, such as the use of linker molecules for covalent binding to the particles, could strongly influence the molecular structure, bioavailability, toxicity, and efficacy of the drug. ${ }^{12}$ Moreover, the magnetic characterization of SPION ${ }^{\text {LA-HSA-Ptx }}$ reveals a high magnetic susceptibility, qualifying them for MDT applications.

A detailed analysis of the short time effects of SPION ${ }^{\text {LA-HSA-Ptx }}$ during the first 48 hours by flow cytometry (Figures S2 and 2; Table S2) revealed a very slight decrease in the impact of SPION ${ }^{\text {LA-HSA-Ptx }}$ compared with free Ptx, indicating that a small fraction of Ptx was still bound to the carrier particles. In addition, free and nanoparticle-bound Ptx showed a clear concentration-dependent toxicity, increasing from 2.25 to 9.0 to $36 \mathrm{nM}$. However, MDA-MB-231 and T-47D were considerably more sensitive toward Ptx than BT-474 and MCF-7 cells. Notably, there were no significant differences between negative controls and cells treated for 24 and 48 hours with $2.25 \mathrm{nM}$ Ptx. Moreover, during the first 48 hours, incubation with $36 \mathrm{nM}$ Ptx did not lead to a general cell death.

However, during long-time incubations, toxic effects of low Ptx amounts were detectable, and treatment with high concentrations of Ptx led to a complete cell death, whereas the growth curves of cells treated with the SPION ${ }^{\text {LA-HSA }}$ carriers were indistinguishable from the negative controls (Figure 3). The IncuCyte ${ }^{\circledR}$ confluency measurements also displayed a Ptx concentration-dependent growth pattern. At $9 \mathrm{nM}$ Ptx, all cells still proliferated, even though the velocity considerably decreased compared with control cells. After a cell-dependent growth maximum within the first 3 days, Ptx treatment led to a reduction or stagnation of the cell growth, indicating a delayed cell death due to the formation of highly stable and dysfunctional microtubules leading to the disruption of normal tubule dynamics and essential interphase processes. ${ }^{6}$ At $36 \mathrm{nM}$, the effects of Ptx were even more effective, resulting in a stronger inhibition of cell proliferation and a faster cell death.

To determine the effects of free and SPION-bound Ptx in $3 \mathrm{D}$ cell culture, we generated multicellular tumor models and incubated them with $36 \mathrm{nM}$ Ptx (Figure 4). BT-474, MCF7, and MDA-MB-231 cells produced disc-like spheroids, containing loosely packed cell aggregates with only a few cell layers, whereas T-47D formed highly compact spheroids. Particularly, MCF-7 cells generated morphologically very heterogenic cell aggregates with inadequate compactness, disqualifying them as a suitable tumor model for the 
investigation of drug effects. However, there were no obvious differences between spheroids in the negative control group and in the SPION ${ }^{\mathrm{LA}-\mathrm{HSA}}$ vehicle control, and between spheroids treated with free Ptx and SPION ${ }^{\text {LA-HSA-Ptx }}$. Thus, we conclude that the toxic effects of SPION ${ }^{\text {LA-HSA-Ptx }}$ were caused by Ptx and not by SPION ${ }^{\text {LA-HSA }}$, and the efficiency of Ptx was not inhibited in the presence of the carrier particles. The progression of BT-474, MDA-MB-231, and T-47D spheroids was strongly affected in the presence of free and SPION-bound Ptx. The growth of MDA-MB-231 and T-47D spheroids was completely inhibited after 24 hours followed by a constant shrinking, whereas BT-474 displayed a growth arrest after 5 days, indicating a complete inhibition of cell proliferation.

\section{Conclusion}

In summary, by analyzing the amount of viable, apoptotic, and necrotic cells as well as the mitochondrial membrane potential, DNA cycle, and DNA degradation, we were able to quantify the short time effects of free Ptx and Ptxfunctionalized SPIONs to breast cancer cells. In addition, we determined the kinetics of long-time Ptx-treatment by recording the 2D cell confluency in Ptx-treated cell culture wells and the impact of Ptx on 3D multicellular spheroids. Our data clearly showed that the binding of the antiproliferative and antitumorigenic agent Ptx to the magnetic susceptible and biocompatible carrier SPION ${ }^{\text {LA-HSA }}$ was effective in different breast cancer cell lines and did not influence the cytotoxic efficiency of the chemotherapeutic drug. The presented $2 \mathrm{D}$ and $3 \mathrm{D}$ cell culture experiments therefore suggest that SPION ${ }^{\text {LA-HSA-Ptx }}$ is a potential system for magnetically based targeted drug delivery to different breast cancer tumors.

\section{Acknowledgments}

The present work was performed in fulfillment of the requirements for obtaining the degree "Dr. med." (Stephan Lugert). This study was supported by the Deutsche Forschungsgemeinschaft (SPP1681: Grant Numbers: AL 552/5-3, VI 892/1-1, and WI 4230/1-2), by the Emerging Fields Initiative BIG-THERA of the Friedrich-Alexander-Universität Erlangen-Nürnberg (FAU) and the Forschungsstiftung Medizin am UK-Erlangen. The authors also acknowledge the support by Deutsche Forschungsgemeinschaft and FAU within the funding program of Open Access Publishing. Eveline Schreiber, Bianca Weigel, and Julia Band are gratefully acknowledged for their expert technical help in the chemistry and cell culture laboratory.

\section{Disclosure}

The authors report no conflicts of interest in this work.

\section{References}

1. Weir HK, Anderson RN, Coleman King SM, et al. Heart Disease and Cancer Deaths - Trends and Projections in the United States, 1969-2020. Prev Chronic Dis. 2016;13:E157.

2. Ferlay J, Soerjomataram I, Dikshit R, et al. Cancer incidence and mortality worldwide: sources, methods and major patterns in GLOBOCAN 2012. Int J Cancer. 2015;136(5):E359-E386.

3. Mctiernan A. Behavioral risk factors in breast cancer: can risk be modified? Oncologist. 2003;8(4):326-334.

4. Cardoso F, Costa A, Senkus E, et al. 3rd ESO-ESMO International Consensus Guidelines for Advanced Breast Cancer (ABC 3). Ann Oncol. 2017;28(12):3111-3133.

5. Cardoso F, Costa A, Senkus E, et al. 3rd ESO-ESMO international consensus guidelines for Advanced Breast Cancer (ABC 3). Breast. 2017;31:244-259.

6. Singla AK, Garg A, Aggarwal D. Paclitaxel and its formulations. Int $J$ Pharm. 2002;235(1-2):179-192.

7. Shapiro CL, Recht A. Side effects of adjuvant treatment of breast cancer. N Engl J Med. 2001;344(26):1997-2008.

8. Lyer S, Singh R, Tietze R, Alexiou C. Magnetic nanoparticles for magnetic drug targeting. Biomed Tech. 2015;60(5):465-475.

9. Tietze R, Zaloga J, Unterweger H, et al. Magnetic nanoparticle-based drug delivery for cancer therapy. Biochem Biophys Res Commun. 2015; 468(3):463-470.

10. Tietze R, Rahn H, Lyer S, et al. Visualization of superparamagnetic nanoparticles in vascular tissue using $\mathrm{X} \mu \mathrm{CT}$ and histology. Histochem Cell Biol. 2011;135(2):153-158.

11. Janko C, Dürr S, Munoz LE, et al. Magnetic drug targeting reduces the chemotherapeutic burden on circulating leukocytes. Int J Mol Sci. 2013;14(4):7341-7355.

12. Tietze R, Lyer S, Dürr S, et al. Efficient drug-delivery using magnetic nanoparticles - biodistribution and therapeutic effects in tumour bearing rabbits. Nanomedicine. 2013;9(7):961-971.

13. Alev M, Egenberger L, Mühleisen L, et al. Targeting of drug-loaded nanoparticles to tumor sites increases cell death and release of danger signals. J Control Release. 2018;285:67-80.

14. Dürr S, Janko C, Lyer S, et al. Magnetic nanoparticles for cancer therapy. Nanotechnol Rev. 2013;2(4):395.

15. Jiang G, Zhang S, Yazdanparast A, et al. Comprehensive comparison of molecular portraits between cell lines and tumors in breast cancer. BMC Genomics. 2016;17(Suppl 7):525.

16. Chekhun S, Bezdenezhnykh N, Shvets J, Lukianova N. Expression of biomarkers related to cell adhesion, metastasis and invasion of breast cancer cell lines of different molecular subtype. Exp Oncol. 2013; 35(3):174-179.

17. Zaloga J, Pöttler M, Leitinger G, et al. Pharmaceutical formulation of HSA hybrid coated iron oxide nanoparticles for magnetic drug targeting. Eur J Pharm Biopharm. 2016;101:152-162.

18. Bica D, Vékás L, Avdeev MV, et al. Sterically stabilized water based magnetic fluids: synthesis, structure and properties. J Magn Magn Mater. 2007;311(1):17-21.

19. Zaloga J, Stapf M, Nowak J, et al. Tangential Flow Ultrafiltration Allows Purification and Concentration of Lauric Acid-/AlbuminCoated Particles for Improved Magnetic Treatment. Int J Mol Sci. 2015; 16(8):19291-19307.

20. Zaloga J, Janko C, Agarwal R, et al. Different storage conditions influence biocompatibility and physicochemical properties of iron oxide nanoparticles. Int J Mol Sci. 2015;16(5):9368-9384.

21. Poller JM, Zaloga J, Schreiber E, et al. Selection of potential iron oxide nanoparticles for breast cancer treatment based on in vitro cytotoxicity and cellular uptake. Int J Nanomedicine. 2017;12:3207-3220. 
22. Mühlberger M, Janko C, Unterweger H, et al. Functionalization of T lymphocytes for magnetically controlled immune therapy: selection of suitable superparamagnetic iron oxide nanoparticles. J Magn Magn Mater. 2019;473:61-67.

23. Munoz LE, Maueröder C, Chaurio R, Berens C, Herrmann M, Janko C. Colourful death: six-parameter classification of cell death by flow cytometry-dead cells tell tales. Autoimmunity. 2013;46(5):336-341.

24. Friedrich RP, Janko C, Poettler M, et al. Flow cytometry for intracellular SPION quantification: specificity and sensitivity in comparison with spectroscopic methods. Int J Nanomedicine. 2015;10:4185-4201.

25. Riccardi C, Nicoletti I. Analysis of apoptosis by propidium iodide staining and flow cytometry. Nat Protoc. 2006;1(3):1458-1461.

26. Gradishar WJ. Albumin-bound paclitaxel: a next-generation taxane. Expert Opin Pharmacother. 2006;7(8):1041-1053.

27. Curry S, Mandelkow H, Brick P, Franks N. Crystal structure of human serum albumin complexed with fatty acid reveals an asymmetric distribution of binding sites. Nat Struct Biol. 1998;5(9):827-835.

28. Calatayud MP, Sanz B, Raffa V, Riggio C, Ibarra MR, Goya GF. The effect of surface charge of functionalized $\mathrm{Fe} 3 \mathrm{O} 4$ nanoparticles on protein adsorption and cell uptake. Biomaterials. 2014;35(24):6389-6399.

29. Tenzer S, Docter D, Kuharev J, et al. Rapid formation of plasma protein corona critically affects nanoparticle pathophysiology. Nat Nanotechnol. 2013;8(10):772-781.

30. Malvern Instruments. Dynamic Light Scattering: An Introduction in 30 Minutes. Technical Note. Malvern: Malvern Instruments. 2012.

31. Paál K, Müller J, Hegedûs L. High affinity binding of paclitaxel to human serum albumin. Eur J Biochem. 2001;268(7):2187-2191.

32. Brabers VAM. Progress in Spinel Ferrite Research. Handbook of Magnetic Materials 8. Amsterdam, Lausanne, New York, Oxford, Tokyo: Elsevier; 1995:199-344.

33. Ludwig F, Balceris C, Jonasson C, Johansson C. Analysis of AC Susceptibility Spectra for the Characterization of Magnetic Nanoparticles. IEEE Trans Magn. 2017;53(11):1-4.

34. Antipas GS, Statharas E, Tserotas P, Papadopoulos N, Hristoforou E. Experimental and first-principles characterization of functionalized magnetic nanoparticles. Chemphyschem. 2013;14(9):1934-1942.

35. Yang H, Yang S, Kong J, Dong A, Yu S. Obtaining information about protein secondary structures in aqueous solution using Fourier transform IR spectroscopy. Nat Protoc. 2015;10(3):382-396.
36. Huang YT, Liao HF, Wang SL, Lin SY. Glycation and secondary conformational changes of human serum albumin: study of the FTIR spectroscopic curve-fitting technique. AIMS Biophys. 2016;3(2): 247-260.

37. Prat A, Perou CM. Deconstructing the molecular portraits of breast cancer. Mol Oncol. 2011;5(1):5-23.

38. Neve RM, Chin K, Fridlyand J, et al. A collection of breast cancer cell lines for the study of functionally distinct cancer subtypes. Cancer Cell. 2006;10(6):515-527.

39. Almutary A, Sanderson BJ. The MTT and Crystal Violet Assays: Potential Confounders in Nanoparticle Toxicity Testing. Int J Toxicol. 2016;35(4):454-462.

40. Kumar G, Degheidy H, Casey BJ, Goering PL. Flow cytometry evaluation of in vitro cellular necrosis and apoptosis induced by silver nanoparticles. Food Chem Toxicol. 2015;85:45-51.

41. Janko C, Munoz L, Chaurio R, et al. Navigation to the graveyardinduction of various pathways of necrosis and their classification by flow cytometry. Methods Mol Biol. 2013;1004:3-15.

42. Liebmann JE, Cook JA, Lipschultz C, Teague D, Fisher J, Mitchell JB. Cytotoxic studies of paclitaxel (Taxol) in human tumour cell lines. Br J Cancer. 1993;68(6):1104-1109.

43. Hirschhaeuser F, Menne H, Dittfeld C, West J, Mueller-Klieser W, Kunz-Schughart LA. Multicellular tumor spheroids: an underestimated tool is catching up again. J Biotechnol. 2010;148(1):3-15.

44. Griffith LG, Swartz MA. Capturing complex 3D tissue physiology in vitro. Nat Rev Mol Cell Biol. 2006;7(3):211-224.

45. Hornung A, Poettler M, Friedrich RP, et al. Treatment efficiency of free and nanoparticle-loaded mitoxantrone for magnetic drug targeting in multicellular tumor spheroids. Molecules. 2015;20(10):18016-18030.

46. Hornung A, Poettler M, Friedrich RP, et al. Toxicity of Mitoxantroneloaded superparamagnetic iron oxide nanoparticles in a HT-29 tumour spheroid model. Anticancer Res. 2016;36(6):3093-3101.

47. Haque $\mathrm{R}$, Ahmed SA, Inzhakova $\mathrm{G}$, et al. Impact of breast cancer subtypes and treatment on survival: an analysis spanning two decades. Cancer Epidemiol Biomarkers Prev. 2012;21(10):1848-1855.

48. Beenken SW, Bland KI. Biomarkers for breast cancer. Minerva Chir. 2002;57(4):437-448. 


\section{Supplementary materials}

A

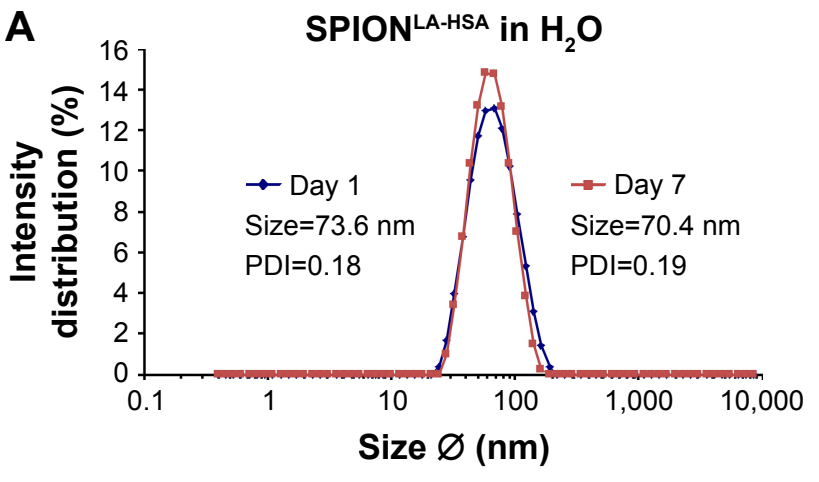

C

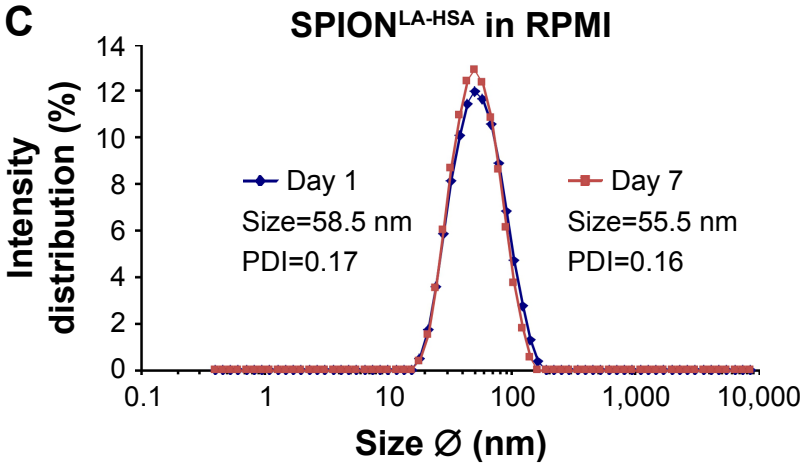

E SPION ${ }^{\text {LA-HSA }}$ in RPMI $+10 \%$ FBS

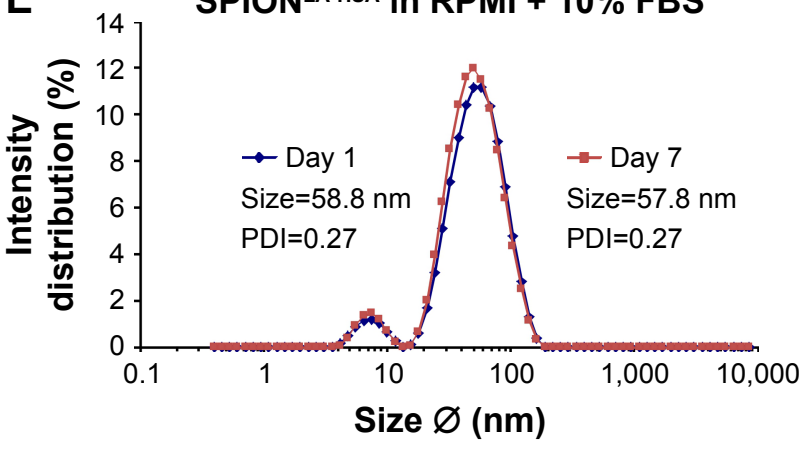

G

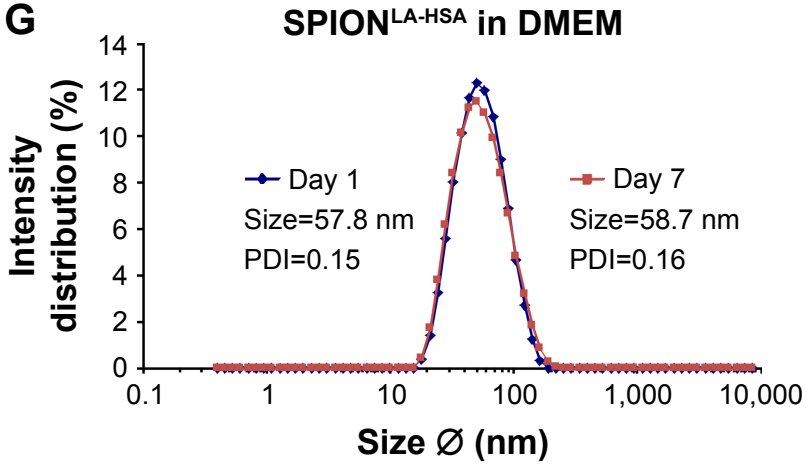

B SPIONLA-HSA-Ptx in $\mathrm{H}_{2} \mathrm{O}$

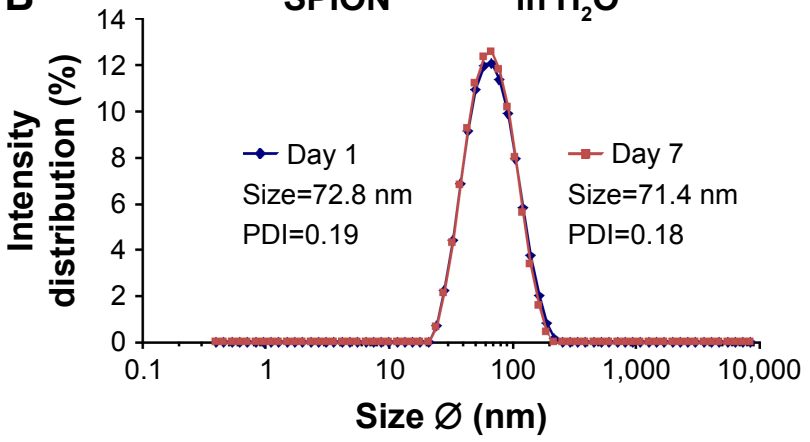

D SPIONLA-HSA-Ptx in RPMI
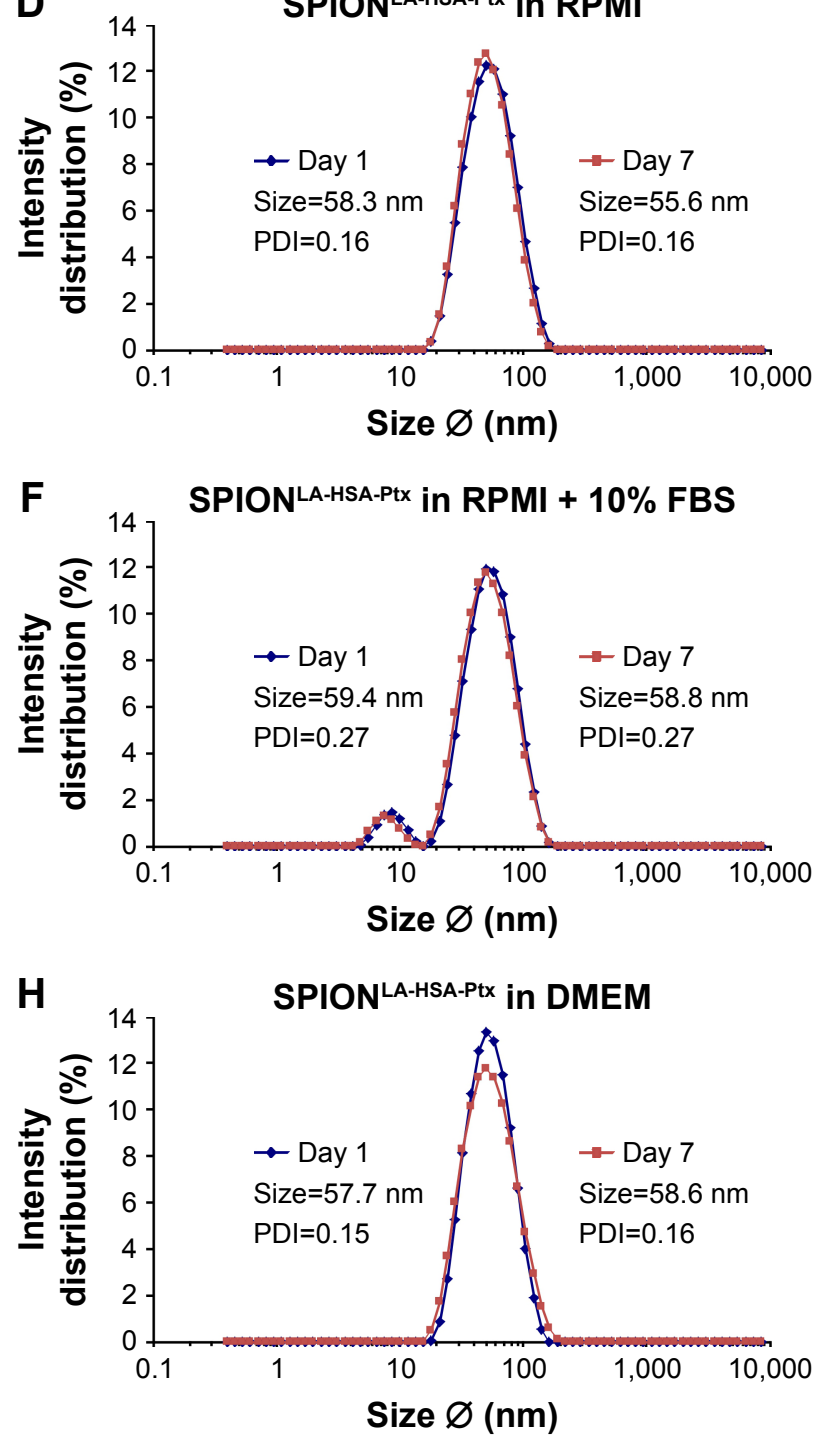

Figure SI (Continued) 

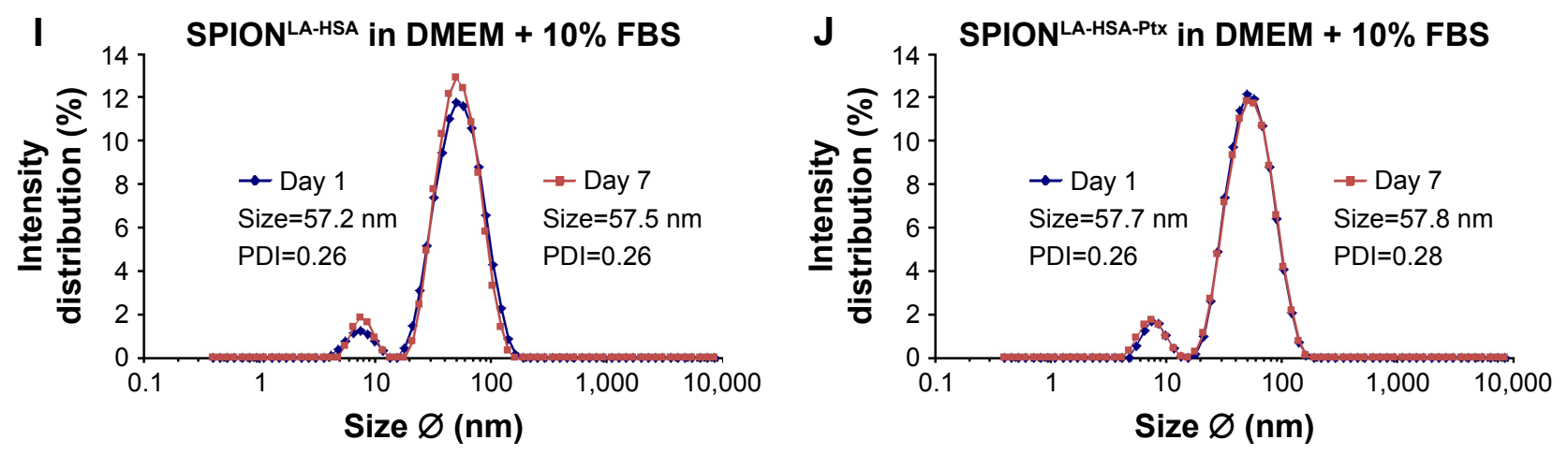

Figure SI Effect of different solvents on the size of SPION ${ }^{\text {LA-HSA-PtX }}$ and SPION ${ }^{\text {LA-HSA }}$.

Notes: SPION $N^{\text {LA-HSA-PtX }}$ and SPION ${ }^{\text {LA-HSA }}$ were diluted in $(\mathbf{A}, \mathbf{B}) \mathrm{H}_{2} \mathrm{O},(\mathbf{C}, \mathbf{D})$ RPMI, (E, F) RPMI + I0\% FBS, (G, H) DMEM, and (I, J) DMEM + I0\% FBS. Z-average and PDI were analyzed on day I after preparation and after 7 days of storage at $4^{\circ} \mathrm{C}$ by DLS, and the results are depicted in representative graphs. The strong increase in the PDI in samples containing $10 \%$ FBS is obviously the result of the additional FBS signal at $7.3 \mathrm{~nm}$.

Abbreviations: DLS, dynamic light scattering; DMEM, Dulbecco's Modified Eagle's Medium; PDI, polydispersity index; Ptx, paclitaxel; SPION, superparamagnetic iron oxide nanoparticles; SPION ${ }^{L A-H S A}$, lauric acid- and human serum albumin-coated SPIONs; SPION ${ }^{\text {LA-HSA-PDx}}$, SPION LA-HSA functionalized with paclitaxel; RPMI, Roswell Park Memorial Institute; Z-average, intensity-weighted harmonic mean size.

Table SI Physicochemical properties of SPION LA-HSA and SPION LA-HSA-Ptx particles

\begin{tabular}{|c|c|c|}
\hline Parameter & SPION & SPIONLA-HSA-Ptx \\
\hline Hydrodynamic size in $\mathrm{H}_{2} \mathrm{O}$ (day I/day 8) $(\mathrm{nm})$ & $73.6 \pm 1.9 / 70.4 \pm 2.9$ & $72.8 \pm 2.0 / 71.4 \pm 0.8$ \\
\hline Hydrodynamic size in RPMI (0\% FBS) (day I/day 8) (nm) & $58.5 \pm 1.1 / 55.5 \pm 0.3$ & $58.3 \pm 1.6 / 55.6 \pm 0.3$ \\
\hline Hydrodynamic size in RPMI (I0\% FBS) (day I/day 8) (nm) & $58.8 \pm 0.6 / 57.8 \pm 0.7$ & $59.4 \pm 0.4 / 58.8 \pm 2.2$ \\
\hline Hydrodynamic size in DMEM (0\% FBS) (day I/day 8) (nm) & $57.8 \pm 0.9 / 58.7 \pm 0.9$ & $57.7 \pm 1.3 / 58.6 \pm 0.6$ \\
\hline Hydrodynamic size in DMEM (I0\% FBS) (day I/day 8) $(\mathrm{nm})$ & $57.2 \pm 1.0 / 57.5 \pm 1.1$ & $57.7 \pm 1.6 / 57.8 \pm 0.4$ \\
\hline $\mathrm{PDI}$ in $\mathrm{H}_{2} \mathrm{O}$ (day $\mathrm{I} /$ day 8 ) & $0.180 \pm 0.009 / 0.194 \pm 0.002$ & $0.185 \pm 0.011 / 0.176 \pm 0.013$ \\
\hline PDI in RPMI (0\% FBS) (day I/day 8) & $0.166 \pm 0.005 / 0.159 \pm 0.003$ & $0.158 \pm 0.017 / 0.156 \pm 0.006$ \\
\hline PDI in RPMI (I0\% FBS) (day I/day 8) & $0.267 \pm 0.002 / 0.268 \pm 0.005$ & $0.267 \pm 0.005 / 0.272 \pm 0.008$ \\
\hline PDI in DMEM (0\% FBS) (day I/day 8) & $0.151 \pm 0.011 / 0.160 \pm 0.014$ & $0.15 \pm 0.013 / 0.162 \pm 0.009$ \\
\hline PDI in DMEM (I0\% FBS) (day I/day 8) & $0.260 \pm 0.002 / 0.263 \pm 0.007$ & $0.263 \pm 0.00 \mathrm{I} / 0.278 \pm 0.005$ \\
\hline$\zeta$ Potential at $\mathrm{pH} 6.28 * / 6.65^{* *}(\mathrm{mV})$ & $-11.2 \pm 0.9$ & $-13.2 \pm 2.9$ \\
\hline$\zeta$ Potential at $\mathrm{pH} \sim 4.0(\mathrm{mV})$ & $21.7 \pm 1.9$ & $23.0 \pm 0.6$ \\
\hline Isoelectric point ( $\zeta=0$ forward reaction) $(\mathrm{pH})$ & $6.07 \pm 0.17$ & $6.37 \pm 0.18$ \\
\hline Isoelectric point ( $\zeta=0$ backward reaction) $(\mathrm{pH})$ & $4.95 \pm 0.10$ & $4.97 \pm 0.05$ \\
\hline Magnetization at $5 \mathrm{~T}(\mathrm{kA} / \mathrm{m})$ & $467 \pm 15$ & $465 \pm 15$ \\
\hline
\end{tabular}

Notes: Summary of the main physicochemical properties of SPION ${ }^{\text {LA-HSA }}$ and SPION ${ }^{\text {LA-HSA-Ptx }}$ particles. The hydrodynamic diameter and PDI of newly prepared particles were measured at day I and additionally after 7 days of storage at $4^{\circ} \mathrm{C}$. *Zeta potential measurement of SPION ${ }^{\text {LA-HSA }}$ at the $\mathrm{pH}$ value of freshly prepared particles. $* *$ Zeta potential measurement of SPION LA-HSA-Ptx at the $\mathrm{PH}$ value of freshly prepared particles.

Abbreviations: DMEM, Dulbecco's Modified Eagle's Medium; FBS, fetal bovine serum; PDI, polydispersity index; Ptx, paclitaxel; RPMI, Roswell Park Memorial Institute; SPION, superparamagnetic iron oxide nanoparticles; SPION ${ }^{\text {LA-HSA }}$, lauric acid- and human serum albumin-coated SPIONs; SPION ${ }^{\text {LA-HSA-PDx }}$, SPION ${ }^{\text {LA-HSA }}$ functionalized with paclitaxel; T, tesla.

A

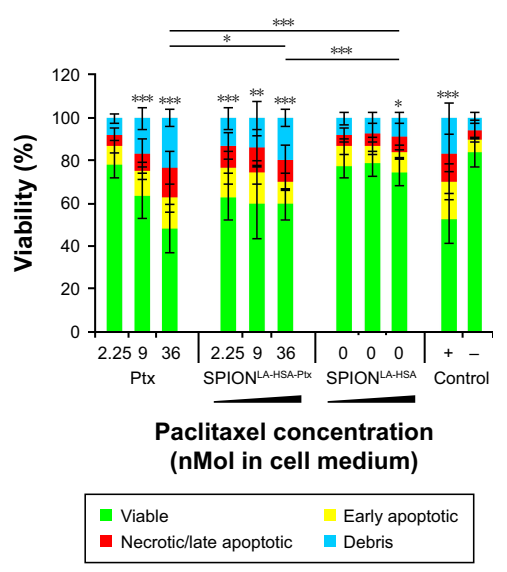

BT-474 24 hours

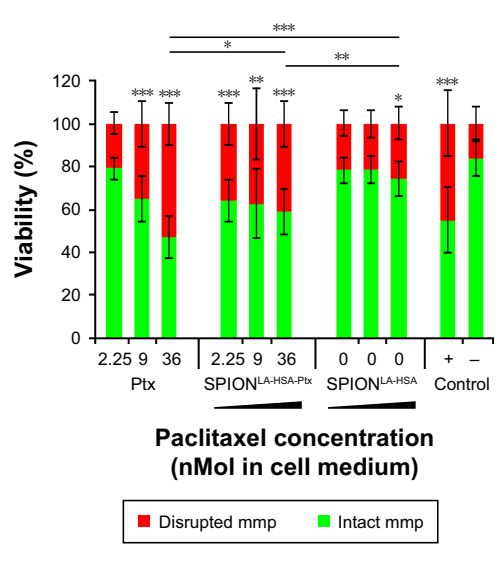

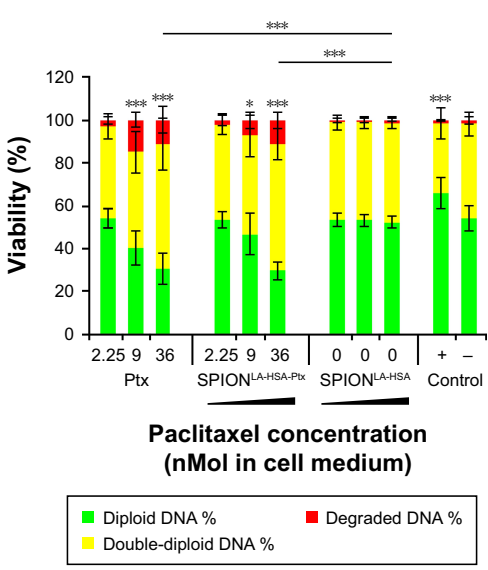

Figure S2 (Continued) 
B

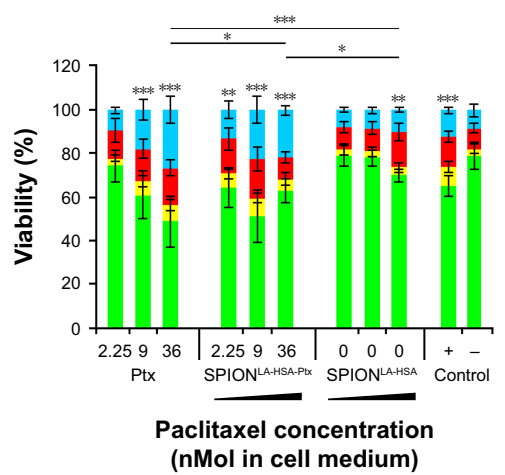

C

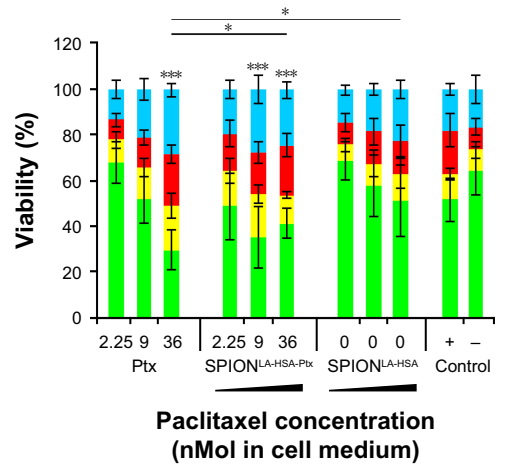

D

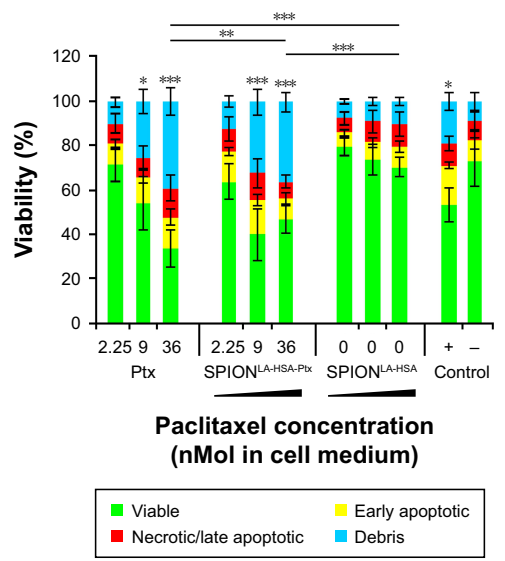

MCF-7 24 hours
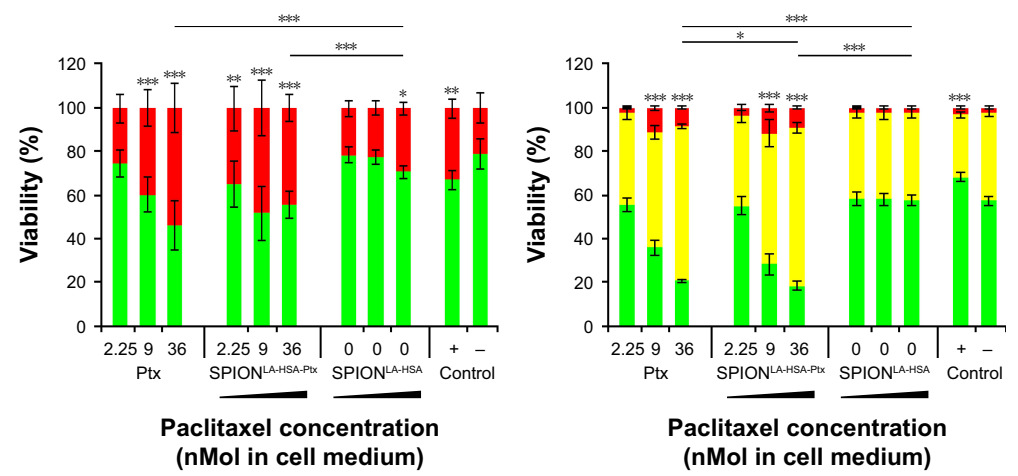

MDA-MB-231 24 hours
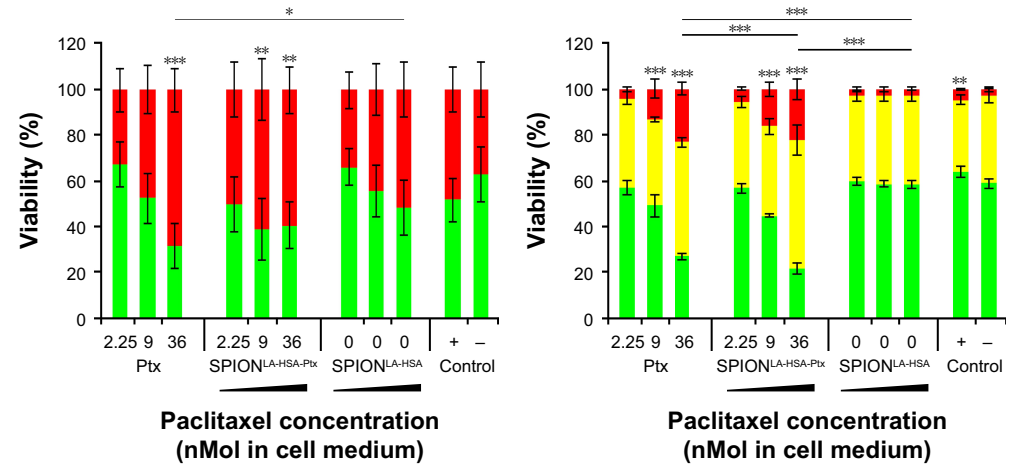

T-47D 24 hours

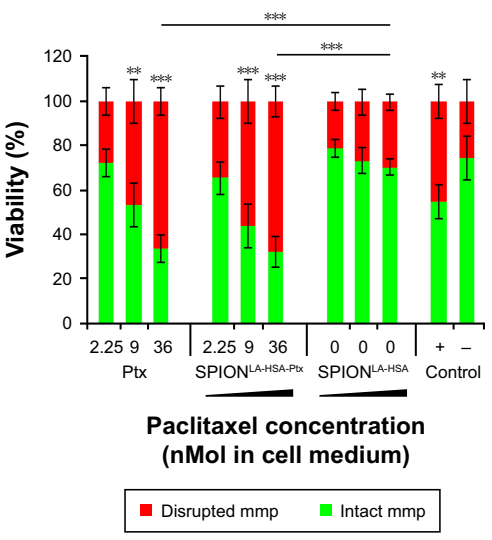

Figure S2 Viability of breast cancer cells 24 hours after Ptx treatment.

Notes: (A) BT-474, (B) MCF-7, (C) MDA-MB-23I, and (D) T-47D cells were incubated for 24 hours with increasing amounts of free Ptx, SPIONLA-HSA-Ptx, and SPION ${ }^{\text {LA-HSA }}$ and analyzed by multiparameter flow cytometry. Viability was determined by AxV-FITC and PI staining (first column), yielding the percentage of viable (Ax- PI-), apoptotic $(\mathrm{Ax}+\mathrm{Pl}-)$, and necrotic $(\mathrm{Pl}+)$ cells. The status of the mitochondrial membrane potential was analyzed by $\mathrm{Dil} \mathrm{Cl}(5)$ staining and distinguished cells with intact $(\mathrm{DilCl}(5)$ positive) and depolarized (DilCl(5) negative) membranes (middle column). DNA degradation and cell cycle were determined by PIT staining and showed the amount of degraded DNA, diploid DNA (GI phase), and double-diploid DNA (synthesis/G2 phase) (last column). Positive controls contain 2\% DMSO, and negative controls represent the corresponding amount of solvent instead of drug or ferrofluid. Data are expressed as the mean \pm SD ( $n=4$ with technical triplicates). Statistical significance of viability, intact membrane potential, and diploid DNA content between control and samples are indicated with $* P<0.01, * * P<0.00 \mathrm{I}$, and $* * * P<0.000 \mathrm{I}$, and were calculated via Student's t-test analysis.

Abbreviations: AxV, Annexin A5; DilCl(5), I,I',3,3,3',3'-hexamethylindodicarbocyanine iodide; DMSO, dimethyl sulfoxide; FITC, fluorescein isothiocyanate; MMP, mitochondrial membrane potential; PI, propidium iodide; PIT, propidium iodide-Triton X-I00; Ptx, paclitaxel; SPION, superparamagnetic iron oxide nanoparticles; SPION ${ }^{\text {LA-HSA }}$, lauric acid- and human serum albumin-coated SPIONs; SPION ${ }^{\text {LA-HSA-Ptx }}$, SPION ${ }^{\text {LA-HSA }}$ functionalized with paclitaxel. 
Table S2 Impact of free Ptx and SPIONLA-HSA-Ptx on breast cancer cell lines

\begin{tabular}{|c|c|c|c|c|c|c|}
\hline Cell line & Effect & Free Ptx & SPIONLA-HSA-Ptx & $\begin{array}{l}\text { SPION } \\
\text { control }\end{array}$ & $\begin{array}{l}\text { Negative } \\
\text { control }\end{array}$ & $\begin{array}{l}\text { Positive } \\
\text { control }\end{array}$ \\
\hline BT-474 & $\begin{array}{l}\text { Viable cells @ } 48 \text { hours (\%) } \\
\text { Early apoptotic cells @ } 48 \text { hours (\%) } \\
\text { Necrotic/late apoptotic cells @ } 48 \text { hours (\%) } \\
\text { Cell debris @ } 48 \text { hours (\%) } \\
\text { Intact MMP @ } 48 \text { hours (\%) } \\
\text { Disrupted MMP @ } 48 \text { hours (\%) } \\
\text { Diploid DNA @ } 48 \text { hours (\%) } \\
\text { Double-diploid DNA @ } 48 \text { hours (\%) } \\
\text { Degraded DNA @ } 48 \text { hours (\%) } \\
\text { Confluency after } 7 \text { days (\%) } \\
\text { 2D spheroid area after } 7 \text { days }\left(\mathrm{mm}^{2}\right)\end{array}$ & $\begin{array}{l}38.5 \pm 9.3 \\
20.3 \pm 6.5 \\
14.7 \pm 7.6 \\
26.6 \pm 3.9 \\
37.4 \pm 6.3 \\
62.6 \pm 6.3 \\
38.3 \pm 3.6 \\
49.5 \pm 3.7 \\
12.2 \pm 0.3 \\
20.9 \pm 8.7 \\
1.31 \pm 0.33\end{array}$ & $\begin{array}{l}57.8 \pm 10.0 \\
15.7 \pm 7.6 \\
10.0 \pm 4.6 \\
16.5 \pm 5.4 \\
59.7 \pm 8.4 \\
40.3 \pm 8.4 \\
38.1 \pm 2.9 \\
51.9 \pm 3.9 \\
10.0 \pm 1.0 \\
20.3 \pm 13.2 \\
1.23 \pm 0.28\end{array}$ & $\begin{array}{l}69.5 \pm 23.3 \\
10.6 \pm 12.3 \\
8.1 \pm 6.8 \\
11.8 \pm 11.2 \\
68.7 \pm 22.1 \\
31.3 \pm 22.1 \\
50.8 \pm 0.9 \\
48.2 \pm 1.2 \\
1.0 \pm 0.5 \\
101.6 \pm 4.7 \\
3.45 \pm 0.49\end{array}$ & $\begin{array}{l}83.0 \pm 8.5 \\
6.0 \pm 1.6 \\
5.4 \pm 5.9 \\
5.5 \pm 3.4 \\
82.2 \pm 9.7 \\
17.8 \pm 9.7 \\
56.0 \pm 4.0 \\
43.1 \pm 4.0 \\
0.9 \pm 0.3 \\
100.0 \pm 4.1 \\
3.30 \pm 0.45\end{array}$ & $\begin{array}{l}55.0 \pm 13.5 \\
20.7 \pm 8.1 \\
10.8 \pm 6.5 \\
13.5 \pm 4.3 \\
58.1 \pm 11.9 \\
41.9 \pm 11.9 \\
67.2 \pm 3.1 \\
31.4 \pm 3.0 \\
1.4 \pm 0.1 \\
76.3 \pm 8.9 \\
2.18 \pm 0.93\end{array}$ \\
\hline MCF-7 & $\begin{array}{l}\text { Viable cells @ } 48 \text { hours (\%) } \\
\text { Early apoptotic cells @ } 48 \text { hours (\%) } \\
\text { Necrotic/late apoptotic cells @ } 48 \text { hours (\%) } \\
\text { Cell debris @ } 48 \text { hours (\%) } \\
\text { Intact MMP @ } 48 \text { hours (\%) } \\
\text { Disrupted MMP @ } 48 \text { hours (\%) } \\
\text { Diploid DNA @ } 48 \text { hours (\%) } \\
\text { Double-diploid DNA @ } 48 \text { hours (\%) } \\
\text { Degraded DNA @ } 48 \text { hours (\%) } \\
\text { Confluency after } 7 \text { days (\%) } \\
\text { 2D spheroid area after } 7 \text { days }\left(\mathrm{mm}^{2}\right)\end{array}$ & $\begin{array}{l}46.0 \pm 5.7 \\
9.7 \pm 3.8 \\
12.7 \pm 1.1 \\
31.6 \pm 2.4 \\
43.4 \pm 2.0 \\
56.6 \pm 2.0 \\
25.5 \pm 4.3 \\
55.9 \pm 8.4 \\
18.7 \pm 5.1 \\
24.0 \pm 3.5 \\
1.19 \pm 0.12\end{array}$ & $\begin{array}{l}54.9 \pm 2.1 \\
5.9 \pm 1.7 \\
10.2 \pm 1.9 \\
28.9 \pm 2.3 \\
47.4 \pm 3.6 \\
52.6 \pm 3.6 \\
22.3 \pm 1.6 \\
60.3 \pm 2.0 \\
17.4 \pm 2.2 \\
22.6 \pm 7.4 \\
1.17 \pm 0.11\end{array}$ & $\begin{array}{l}73.3 \pm 5.8 \\
0.9 \pm 0.5 \\
16.7 \pm 3.1 \\
9.1 \pm 2.8 \\
74.2 \pm 6.3 \\
25.8 \pm 6.3 \\
61.6 \pm 1.3 \\
35.1 \pm 1.3 \\
3.3 \pm 0.4 \\
96.7 \pm 0.7 \\
1.35 \pm 0.15\end{array}$ & $\begin{array}{l}78.2 \pm 4.9 \\
1.8 \pm 0.9 \\
11.2 \pm 3.5 \\
8.8 \pm 1.7 \\
77.7 \pm 4.8 \\
22.3 \pm 4.8 \\
61.5 \pm 1.2 \\
35.4 \pm 1.6 \\
3.1 \pm 0.6 \\
96.5 \pm 0.8 \\
1.34 \pm 0.08\end{array}$ & $\begin{array}{l}63.7 \pm 6.7 \\
7.4 \pm 1.9 \\
14.9 \pm 2.8 \\
14.0 \pm 4.2 \\
63.7 \pm 8.9 \\
36.6 \pm 8.9 \\
65.9 \pm 1.0 \\
30.9 \pm 1.1 \\
3.2 \pm 0.6 \\
29.6 \pm 10.5 \\
0.80 \pm 0.10\end{array}$ \\
\hline MDA-MB-23I & $\begin{array}{l}\text { Viable cells @ } 48 \text { hours (\%) } \\
\text { Early apoptotic cells @ } 48 \text { hours (\%) } \\
\text { Necrotic/late apoptotic cells @ } 48 \text { hours (\%) } \\
\text { Cell debris @ } 48 \text { hours (\%) } \\
\text { Intact MMP @ } 48 \text { hours (\%) } \\
\text { Disrupted MMP @ } 48 \text { hours (\%) } \\
\text { Diploid DNA @ } 48 \text { hours (\%) } \\
\text { Double-diploid DNA @ } 48 \text { hours (\%) } \\
\text { Degraded DNA @ } 48 \text { hours (\%) } \\
\text { Confluency after } 7 \text { days (\%) } \\
\text { 2D spheroid area after } 7 \text { days }\left(\mathrm{mm}^{2}\right)\end{array}$ & $\begin{array}{l}18.2 \pm 13.8 \\
22.2 \pm 4.5 \\
30.0 \pm 9.9 \\
29.7 \pm 5.4 \\
23.6 \pm 13.8 \\
76.4 \pm 13.8 \\
29.6 \pm 2.0 \\
39.4 \pm 10.9 \\
31.0 \pm 9.3 \\
14.7 \pm 8.8 \\
1.02 \pm 0.09\end{array}$ & $\begin{array}{l}27.5 \pm 4.9 \\
17.8 \pm 3.9 \\
27.3 \pm 4.4 \\
27.4 \pm 2.7 \\
31.1 \pm 9.9 \\
68.9 \pm 9.9 \\
25.6 \pm 5.7 \\
44.0 \pm 15.9 \\
30.4 \pm 10.3 \\
12.5 \pm 8.2 \\
1.11 \pm 0.11\end{array}$ & $\begin{array}{l}67.1 \pm 9.4 \\
6.8 \pm 5.1 \\
9.5 \pm 2.7 \\
16.5 \pm 2.7 \\
64.0 \pm 7.8 \\
36.0 \pm 7.8 \\
61.5 \pm 1.2 \\
35.6 \pm 1.1 \\
2.9 \pm 0.6 \\
95.0 \pm 0.9 \\
3.28 \pm 0.23\end{array}$ & $\begin{array}{l}70.9 \pm 3.1 \\
6.3 \pm 2.7 \\
8.3 \pm 2.6 \\
14.4 \pm 2.1 \\
68.7 \pm 2.3 \\
31.3 \pm 2.3 \\
61.8 \pm 0.8 \\
34.9 \pm 0.8 \\
3.3 \pm 0.8 \\
96.7 \pm 0.8 \\
2.95 \pm 0.17\end{array}$ & $\begin{array}{l}55.9 \pm 12.1 \\
12.2 \pm 4.5 \\
17.9 \pm 4.9 \\
14.0 \pm 3.3 \\
57.7 \pm 11.6 \\
42.3 \pm 11.6 \\
64.0 \pm 2.1 \\
30.9 \pm 2.5 \\
5.1 \pm 1.0 \\
78.3 \pm 26.5 \\
1.09 \pm 0.16\end{array}$ \\
\hline T-47D & $\begin{array}{l}\text { Viable cells @ } 48 \text { hours (\%) } \\
\text { Early apoptotic cells @ } 48 \text { hours (\%) } \\
\text { Necrotic/late apoptotic cells @ } 48 \text { hours (\%) } \\
\text { Cell debris @ } 48 \text { hours (\%) } \\
\text { Intact MMP @ } 48 \text { hours (\%) } \\
\text { Disrupted MMP @ } 48 \text { hours (\%) } \\
\text { Diploid DNA @ } 48 \text { hours (\%) } \\
\text { Double-diploid DNA @ } 48 \text { hours (\%) } \\
\text { Degraded DNA @ } 48 \text { hours (\%) } \\
\text { Confluency after } 7 \text { days (\%) } \\
\text { 2D spheroid area after } 7 \text { days }\left(\mathrm{mm}^{2}\right)\end{array}$ & $\begin{array}{l}16.6 \pm 3.5 \\
25.3 \pm 3.7 \\
13.2 \pm 4.3 \\
44.8 \pm 2.5 \\
22.0 \pm 4.4 \\
78.0 \pm 4.4 \\
23.9 \pm 2.2 \\
31.1 \pm 2.2 \\
45.0 \pm 1.4 \\
11.2 \pm 2.7 \\
0.42 \pm 0.03\end{array}$ & $\begin{array}{l}28.0 \pm 6.6 \\
19.2 \pm 1.3 \\
12.3 \pm 7.8 \\
40.5 \pm 3.0 \\
27.6 \pm 5.9 \\
72.4 \pm 5.9 \\
24.6 \pm 1.4 \\
29.9 \pm 1.0 \\
45.5 \pm 1.8 \\
11.2 \pm 1.8 \\
0.43 \pm 0.03\end{array}$ & $\begin{array}{l}74.9 \pm 5.8 \\
3.4 \pm 3.1 \\
6.6 \pm 3.1 \\
9.1 \pm 2.7 \\
75.0 \pm 6.5 \\
25.0 \pm 6.5 \\
66.2 \pm 1.8 \\
29.8 \pm 1.9 \\
4.1 \pm 0.6 \\
64.9 \pm 8.0 \\
0.89 \pm 0.06\end{array}$ & $\begin{array}{l}80.4 \pm 2.4 \\
7.7 \pm 1.7 \\
5.1 \pm 1.4 \\
6.8 \pm 1.2 \\
80.8 \pm 2.9 \\
19.2 \pm 2.9 \\
66.9 \pm 2.4 \\
29.3 \pm 2.2 \\
3.8 \pm 0.4 \\
62.3 \pm 7.9 \\
0.87 \pm 0.05\end{array}$ & $\begin{array}{l}45.2 \pm 9.6 \\
23.1 \pm 4.8 \\
10.9 \pm 5.1 \\
20.8 \pm 4.6 \\
45.9 \pm 9.5 \\
54.1 \pm 9.5 \\
73.6 \pm 1.7 \\
20.0 \pm 2.4 \\
6.4 \pm 1.5 \\
60.4 \pm 2.2 \\
0.42 \pm 0.07\end{array}$ \\
\hline
\end{tabular}

Notes: Summary of short- (48 hours) and long-time (7 days) effects caused by 36 nM free Ptx and particle-bound Ptx on BT-474, MCF-7, MDA-MB-23I, and T-47D cells. Data were extracted from the $2 \mathrm{D}$ and $3 \mathrm{D}$ cell culture experiments shown in the main article. For comparison, positive controls containing $2 \%$ DMSO, negative controls representing the corresponding amount of solvent instead of drug or ferrofluid, and carrier controls containing SPION ${ }^{L A-H S A}$ particles were included.

Abbreviations: DMSO, dimethyl sulfoxide; MMP, mitochondrial membrane potential; Ptx, paclitaxel; SPION, superparamagnetic iron oxide nanoparticles; SPION ${ }^{L A-H S A}$, lauric acid- and human serum albumin-coated SPIONs; SPION ${ }^{\text {LA-HSA-PAx }}$, SPION ${ }^{\text {LA-HSA }}$ functionalized with paclitaxel; 3D, three-dimensional; 2D, two-dimensional. 


\section{Publish your work in this journal}

The International Journal of Nanomedicine is an international, peerreviewed journal focusing on the application of nanotechnology in diagnostics, therapeutics, and drug delivery systems throughout the biomedical field. This journal is indexed on PubMed Central,

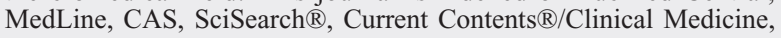

Journal Citation Reports/Science Edition, EMBase, Scopus and the Elsevier Bibliographic databases. The manuscript management system is completely online and includes a very quick and fair peer-review system, which is all easy to use. Visit http://www.dovepress.com/ testimonials.php to read real quotes from published authors.

Submit your manuscript here: http://www.dovepress.com/international-journal-of-nanomedicine-journal 